\title{
EVALUASI MUTU TUNA LOIN SEGAR UNTUK SASHIMI YANG DIOLAH DI ATAS PERAHU SELAMA PENANGANAN DAN DISTRIBUSINYA DI AMBON
}

\section{Evaluation of Fresh Tuna Loin Quality for Sashimi Processed on Boat during Handling and Distribution in Ambon}

\author{
Theresia Dwi Suryaningrum*, Diah Ikasari, dan Hasta Octavini \\ Balai Besar Riset Pengolahan Produk dan Bioteknologi Kelautan dan Perikanan, \\ JI. KS Tubun Petamburan VI, Slipi, Jakarta, Indonesia \\ * Korespondensi Penulis: td.suryaningrum@gmail.com
}

Diterima: 3 Maret 2017; Direvisi: 15 Mei 2017; Disetujui: 11 Desember 2017

\begin{abstract}
ABSTRAK
Penelitian ini bertujuan untuk mengevaluasi mutu tuna loin segar untuk sashimi yang diolah di atas perahu oleh nelayan skala kecil di kota Ambon. Pengamatan dilakukan terhadap mutu tuna loin segar saat didaratkan, dikemas dan ketika tiba di tempat pengiriman, yang meliputi suhu pusat, $\mathrm{pH}$, TVB, Angka Lempeng Total (ALT), serta sifat sensorinya. Pengamatan juga dilakukan terhadap kondisi sanitasi, sarana dan prasarana yang digunakan dengan menggunakan metode swab terhadap cemaran mikroba yang meliputi ALT, E. coli dan Salmonella. Pada tahap akhir dilakukan evaluasi implementasi Good Manufacturing Practice (GMP) dengan menilai sarana dan prasarana berdasarkan persyaratan teknik dalam KEPMEN No. 52A/KEPMEN/ 2013. Hasil penelitian menunjukkan suhu pusat loin berkisar antara $10,58-16,53{ }^{\circ} \mathrm{C}$, jauh di atas suhu untuk tuna sashimi yaitu maksimal $4,4^{\circ} \mathrm{C}$. Kandungan TVB tuna loin yang didaratkan berkisar antara 13,6-14,04 mgN\%, yang mengindikasikan bahwa tuna loin tergolong segar. Secara sensori, panelis mengidentifikasi adanya lapisan pelangi tipis pada permukaan loin segar yang menunjukkan ikan mengalami stres sebelum dimatikan. Pengiriman loin segar keluar kota Ambon berpengaruh terhadap penurunan mutu sensori serta peningkatan jumlah ALT. Tuna loin yang didaratkan di pos pendaratan terlebih dahulu menyebabkan terjadinya penurunan nilai sensori dan peningkatan jumlah ALT yang lebih cepat, namun demikian tuna loin masih tetap tergolong segar ketika sampai di tempat pengiriman. Hasil swab pada kapal, miniplant dan es yang digunakan menunjukkan jumlah bakteri berkisar antara $10^{5}-10^{6} \mathrm{koloni} / \mathrm{g}$, mengindikasikan kondisi sanitasi yang kurang terjaga. Hasil evaluasi terhadap implementasi GMP pada miniplant yang digunakan menunjukkan hanya 59\% kriteria memenuhi persyaratan yang ditetapkan.
\end{abstract}

KATA KUNCI : evaluasi GMP, tuna loin, sanitasi, penanganan, distribusi

\begin{abstract}
Study aimed to evaluate fresh tuna loin quality for sashimi processed on boat by small scale fishermen in Ambon. Observation was conducted on the quality of fresh tuna loin during landing, packaging, and final delivery point, for central temperature, $\mathrm{pH}, \mathrm{TVB}$, total plate count (TPC) and sensory properties. Observation was also done on the sanitation condition of facilities and equipments used in tuna loin processing by using swab method on the parameter of microorganism contaminant such as Total Plate Count (TPC), E coli and Salmonella. At final stage, evaluation of Good Manufacturing Practice (GMP) implementation was done by assessing several criteria of facilities and equipments based on technical requirements stated in KEPMEN no 52A/KEPMEN/ 2013. The results showed that the central temperature of loin ranged between $10.56-16.53{ }^{\circ} \mathrm{C}$, far above the temperature for tuna sashimi i.e $4.4^{\circ} \mathrm{C}$. TVB content of tuna loin was ranging from 13.6 to $14.04 \mathrm{mgN} \%$, indicating that the loin were still fresh. Based on sensory evaluation, the panelists identified the presence of thin rainbow layer on the loin's surface, indicating that the fish experienced stress before died. Delivery process of fresh tuna loin out of Ambon city affected to the decrease of sensory scores as well as the increase of total plate count (TPC) values. Tuna loin which was firstly landed in landing post resulted the decrease of sensory scores and increase of bacterial content, however, the loin was still categorized as fresh for sashimi when arrived at the delivery point. Results of swab test on inner boat's surface, miniplant and ice crushed used in processing stage showed that they contained bacteria ranged from $10^{5}-10^{6}$ colonies $/ g$, indicating less maintained sanitary conditions. Evaluation on the GMP implementation of the miniplant showed that only 59\% criteria met the required GMP.
\end{abstract}

KEYWORDS: evaluation GMP, tuna loin, sanitation, handling, distribution 


\section{PENDAHULUAN}

Wilayah perairan kota Ambon memiliki sumberdaya perikanan yang berperan penting dalam pengembangan ekonomi maupun sosial. Tercatat kontribusi terhadap Produk Domestik Regional Bruto (PDRB) mencapai $17 \%$ per tahun dengan pertumbuhan yang relatif stabil, yaitu $4,5 \%$ per tahun (Sangaji, Mustaruddin \& Wisudo, 2013). Salah satu hasil perikanan yang memiliki nilai ekonomi cukup tinggi adalah tuna, sehingga dapat dijadikan andalan ekspor untuk meningkatkan PDRB di Ambon. Usaha penangkapan tuna di Ambon melibatkan 2.764 perahu nelayan tradisional penangkap tuna dan alat tangkap berupa pancing tonda (troll line) (Anon., 2015). Penangkapan tuna oleh nelayan kecil dilakukan one day fishing (penangkapan satu hari), dengan menggunakan perahu motor tempel 15 PK. Perahu yang digunakan berukuran kecil tidak dilengkapi dengan palka berinsulasi, sehingga apabila ikan didaratkan dalam bentuk utuh, mutu tuna sering kali tidak masuk dalam grade sashimi. Namun jika mutu tuna dapat dipertahankan segar dan masuk ke dalam grade sashimi harganya mencapai 3 kali lipat daripada tuna grade biasa. Mengingat harga tuna loin yang masuk ke dalam grade sashimi cukup tinggi, maka nelayan tuna di Ambon dan juga di beberapa tempat lain, cenderung untuk melakukan penangkapan tuna one day fishing yang diikuti dengan aktivitas penanganan dan pemrosesan menjadi loin di atas perahu, kemudian disimpan di dalam stirofoam yang diberi es. Dengan cara demikian mutu tuna loin segar untuk sashimi dapat dipertahankan, dibandingkan jika tuna didaratkan dalam bentuk gelondongan/utuh.

Namun demikian penanganan dan pengolahan tuna loin di atas perahu dilakukan dengan sarana yang tidak memadai. Kondisi sanitasi perahu yang digunakan untuk penanganan ikan tidak terjamin kebersihannya, sehingga berisiko terjadi kontaminasi yang berakibat menurunnya mutu tuna loin selama distribusi dan pemasarannya (Siregar, Siregar, \& Zahro, 2014). Disisi lain penangkapan tuna dilakukan dengan menggunakan pancing dan ikan dimatikan dengan cara memukul kepalanya, sehingga ikan meronta ronta sebelum mati. Ikan yang meronta ronta sebelum mati dapat menyebabkan terjadinya peningkatan suhu tuna secara cepat, dan bahkan dapat mencapai $30-40{ }^{\circ} \mathrm{C}$ (Syarif, Suwardiyono \& Gautama, 2012; Wibowo, Utomo, Suherman \& Putro, 2007). Kelemahan lain pembunuhan ikan dengan cara tersebut, yaitu fase rigormortis akan dilampaui dengan singkat sehingga proses pembusukan ikan akan lebih mudah terjadi (Syarif et al., 2012). Cara mematikan ikan yang tidak benar juga dapat menyebabkan terjadinya proses metabolisme glikogen dan terbentuknya asam laktat pada jaringan otot sehingga menyebabkan warna daging menjadi pucat atau matang (yake) dan berpengaruh terhadap mutu tuna loin yang dihasilkan (Goodrick, Thomas, Paterson \& Smart, 2002; Maeda, Yaguchi, Fukushima, Harada, \& Fukuda, 2014; Wibowo et al., 2007). Seharusnya penanganan tuna dimulai sejak ikan ditangkap di laut, didaratkan di atas kapal, dimatikan, dilakukan pendarahan dan dibersihkan serta disimpan dalam es dengan baik pada suhu sekitar $-0,5^{\circ} \mathrm{C}$ sampai $1^{\circ} \mathrm{C}$ sehingga suhu ideal untuk tuna sashimi $0^{\circ} \mathrm{C}$ dapat tercapai (Blanc, Desurmont, \& Beverly, 2005; Wibowo et al., 2007). Masalah lain yang dihadapi oleh nelayan kecil di Ambon adalah perahu penangkap tuna yang tidak dilengkapi dengan pelindung panas matahari dan palka berinsulasi. Akibatnya, tuna terpapar panas matahari selama penanganan di atas perahu dan proses pendinginan yang dilakukan tidak mampu untuk menurunkan suhu pusat tuna loin menjadi maksimal $4,4^{\circ} \mathrm{C}$ secara cepat sesuai persyaratan (BSN, 2006 $)$.

Tuna loin hasil tangkapan nelayan kemudian didaratkan di pos pendaratan atau miniplant yang berupa unit pengolahan tuna loin skala rumah tangga. Fasilitas yang digunakan untuk penanganan tuna loin baik di pos pendaratan dan miniplant menggunakan fasilitas seadanya jauh dari prinsip Good Handling Practice (GHP) dan Good Manufacturing Practice (GMP) sehingga kondisi sanitasi dan higiene tidak memadai (Jati, Nurani \& Iskandar, 2014; Siregar et al., 2014). Hal ini dapat berisiko menyebabkan terjadinya proses kemunduran mutu yang cepat dan kemungkinan kontaminasi bakteri pathogen seperti E. colidan Salmonella. Kejadian pencemaran bakteri patogen pada tuna loin dari Indonesia berakibat ditolaknya ekspor tuna ke Amerika (Jati et al., 2014). Hasil penelitian mengenai penanganan dan pengolahan ikan tuna loin segar di atas kapal hingga dikirim kepada suplaier di desa Asilulu Ambon telah dilakukan oleh Siregar et al., (2014). Diperoleh informasi bahwa proses trimming di tingkat suplier yang berlokasi di pinggir-pinggir pantai dilakukan dengan tidak bersih dan saniter, pencucian peralatan menggunakan air laut yang tidak bersih. Penerapan rantai dingin selama pemrosesan tuna loin segar sejak di atas kapal hingga pada tingkat penyuplai tidak dapat dilakukan dengan baik karena suhu rata-rata pada setiap prosesnya lebih tinggi dari $4,4^{\circ} \mathrm{C}$ dan teknik pendinginannya tidak benar. Mengenai masalah sanitasi dan higiene yang belum mendukung rantai pasok perikanan tuna loin di Maluku juga di kemukakan pada hasil penelitian sebelumnya (Jati et al. 2014).

Oleh karena itu diperlukan evaluasi terhadap cara penanganan dan pengolahan tuna loin segar oleh nelayan kecil di Ambon, yaitu evaluasi terhadap penurunan mutu tuna loin mulai saat ikan didaratkan hingga distribusinya, terhadap mutu kimia, mikrobiologis maupun sensori, kondisi sanitasi prasarana yang digunakan dan implementasi GMP pada penanganan tuna loin. Dari penelitian ini 
diharapkan dapat diperoleh data dan informasi yang dapat digunakan sebagai landasan pengambilan kebijakan bagi Pemerintah Daerah dalam upaya perbaikannya.

\section{BAHAN DAN METODE}

\section{Bahan}

Bahan yang digunakan untuk penelitian evaluasi penurunan mutu tuna loin adalah tuna sirip kuning (yellow fin tuna; Thunnus albacares) hasil tangkapan nelayan kecil yang di daratkan di Ambon dalam bentuk loin yang masih ada kulitnya (skin on/loin kotor) ukuran 9-16 kg/loin. Sampel tuna loin dari perahu dikemas dalam plastik PE (poly ethylene) dengan ketebalan plastik 0,3-0,5 mm dan lebar $25-30 \mathrm{~cm}$. Sampel tuna loin diambil di dua titik yaitu:

(A) di tempat pengolahan tuna loin skala rumah tangga (miniplant) di Waitatiri, Kecamatan Tial, Ambon yang merupakan hasil tangkapan nelayan di Desa Tial,

(B) di pos pendaratan tuna loin di Desa Latuhalat, Kecamatan Nusaniwe, Ambon.

\section{Metode}

Untuk mengevaluasi cara penanganan dan pengolahan tuna loin oleh nelayan kecil di Ambon dan distribusinya tersebut, kegiatan penelitian yang dilakukan meliputi (1) evaluasi penurunan mutu tuna loin yang terjadi di sepanjang rantai distribusi baik di miniplant (A) maupun di tempat pendaratan (B), (2) evaluasi kondisi sarana prasarana pengolahan yang digunakan, dan (3) evaluasi implementasi GMP di miniplant tuna loin. Selain itu, dalam penelitian tersebut juga dilakukan observasi dan wawancara untuk mendapatkan gambaran umum penanganan dan pengolahan tuna loin oleh nelayan kecil di atas kapal.

\section{Evaluasi penurunan mutu tuna loin}

Evaluasi penurunan mutu tuna loin dilakukan terhadap tuna hasil tangkapan nelayan kecil di Ambon yang diolah menjadi loin di atas perahu. Sampel diambil di (A) miniplant (tempat pengolahan tuna loin skala rumah tangga) di Waitatiri, Kecamatan Tial, Kabupaten Ambon, dan (B) di pos pendaratan tuna loin di Desa Latuhalat, Kecamatan Nusaniwe, Kabupaten Ambon. Tuna loin yang di ambil dari pos pendaratan sudah dies semalam kemudian keesokan harinya sampel dikirim ke miniplant di Ambon. Pengambilan sampel dilakukan masing-masing dari 3 nelayan di Waitatiri dan Latuhalat. Sampel tuna loin yang diambil di kedua titik tersebut kemudian diikuti penurunan mutunya di sepanjang rantai distribusinya.

\section{Tuna loin yang didaratkan di miniplant}

Tuna loin skin on yang didaratkan oleh nelayan dikemas menggunakan plastik khusus untuk tuna loin, lalu dicelupkan ke dalam larutan kaporit 200 ppm selama 10 detik untuk mencegah terjadinya kontaminasi bakteri patogen. Selanjutnya tuna loin dikeluarkan dari plastik dan dilakukan pengkulitan (skinning) dan perapihan (trimming), sehingga menjadi tuna loin tanpa kulit (skin less). Tuna loin skin less kemudian dikemas dengan plastik PE (tebal 0,3-0,5 $\mathrm{mm}$ dan lebar $25-30 \mathrm{~cm}$ ), dicelup larutan kaporit 200 ppm selama 10 detik dan dies dengan es curai di dalam kotak stirofom dengan perbandingan es dan ikan adalah 1:1.

Tuna loin skin less lalu didiamkan selama semalam kemudian dikeluarkan dari plastiknya dan dirapikan kembali (trimming) untuk menghilangkan daging yang pucat. Tuna loin yang sudah dirapikan kemudian dibungkus dengan kertas busa kemudian dimasukkan kembali ke dalam kantong plastik (PE tebal 0,3-0,5 mm dan lebar $25-30 \mathrm{~cm}$ ) dan divakum dengan menggunakan mesin vakum rumah tangga (penyedot debu). Tuna loin dalam kemasan vakum direndam air es $\left(2-4^{\circ} \mathrm{C}\right)$ selama 30 menit kemudian dikemas dalam kotak stirofoam ex Garuda. Pada bagian dasar kotak stirofoam dilapisi lembaran plastik dan kertas koran. Tuna loin kemudian di atur satu persatu sehingga setiap kotak stirofoam berisi 7-8 loin tergantung ukuran loin. Untuk mempertahankan suhu selama transportasi ke dalam kotak stirofoam diberi es yang dibungkus plastik sebanyak 4 kantong plastik, dengan berat es masing-masing $500 \mathrm{~g}$. Sebelum kotak stirofoam ditutup, di atas loin ditutup dengan kertas koran, kemudian kotak stirofoam dibungkus dengan menggunakan plastik dengan ketebalan 0,6 mm selanjutnya dikirim ke luar kota Ambon (Denpasar).

Dengan mempertimbangkan keterbatasan waktu dan biaya pengamatan selama distribusi yaitu pengiriman ke luar Ambon, dilakukan dengan simulasi seperti pengiriman tuna loin dari Ambon ke Denpasar dengan pesawat terbang. Simulasi dilakukan di Laboratorium Kimia BKIPM Ambon dengan menempatkan sampel (dalam kemasan kotak stirofom) pada suhu ruang (suhu $29,2^{\circ} \mathrm{C}$ ) selama 2 jam sebagai simulasi perjalanan dari miniplant ke bandara. Selanjutnya sampel disimpan dalam ruangan (2 $\times 1,5 \mathrm{~m})$ yang berpendingin yang suhunya diatur sekitar $16{ }^{\circ} \mathrm{C}$ selama 3,5 jam (sebagai simulasi perjalanan di pesawat dari Ambon ke Denpasar). Selanjutnya sampel dipindahkan ke suhu ruang selama 1,5 jam (sebagai simulasi perjalanan dari bandara Denpasar ke UPI di Denpasar). Sampel kemudian dibongkar untuk dilakukan pengamatan.

\section{Tuna loin yang didaratkan di pos pendaratan}

Tuna hasil tangkapan nelayan ditangani dan diproses menjadi loin di atas perahu kemudian 
didaratkan di pos pendaratan. Tuna loin kemudian dibersihkan dari kotoran yang menempel, isi perut dan tulang dan selanjutnya dimasukkan ke dalam kantong plastik (PE tebal 0,3-0,5 mm dan lebar $25-30 \mathrm{~cm}$ ) dan disimpan di dalam kotak stirofoam dan dies (di luar kantong plastik tuna) semalaman dengan perbandingan es dan ikan 1:1. Tuna loin yang sudah di es selanjutnya dikirim ke miniplant, di Waitatiri. Tuna loin kemudian dikuliti (skinning) dan di trimming hingga menjadi tuna loin bersih dan di masukkan ke dalam plastik (PE tebal 0,3-0,5 mm dan lebar 25-30 $\mathrm{cm}$ ) kemudian dicelupkan ke dalam larutan kaporit 200 ppm. Tuna loin kemudian dies kembali dalam kotak stirofoam dengan perbandingan es dan ikan 1:1. Tuna loin skin less yang sudah dies semalam dikeluarkan dari plastiknya dan dirapikan kembali (trimming) untuk menghilangkan daging pucatnya, kemudian dibungkus dengan kertas busa dan dimasukkan ke dalam plastik kemudian divacuum. Tuna loin yang sudah divakum direndam air es $\left(2-4^{\circ} \mathrm{C}\right)$ selama 30 menit, kemudian dikemas dan dikirim dengan prosedur seperti prosedur tuna loin yang didaratkan di miniplant (A).

\section{Pengamatan terhadap parameter mutu}

Pengamatan terhadap tuna loin dilakukan pada 3 titik, yaitu (1) ketika tuna loin didaratkan, (2) ketika tuna loin akan dikemas/dikirim, dan (3) setelah tuna Ioin sampai ditempat tujuan (dengan simulasi). Pengamatan dilakukan dengan mengambil 3 loin dari nelayan yang berbeda yang telah diamati parameter fisiknya kemudian dipotong menjadi 2 untuk pengamatan kimia, mikrobiologi dan sensori. Pengamatan fisik (suhu pusat ikan), kimia (kadar air dan TVB), mikrobiologi dan sensori dilakukan di Lab BKIPM Ambon. Sedangkan analisis proksimat dan verifikasi Salmonela sp. dan E. colidilakukan di Balai Besar Riset Pengolahan Produk dan Bioteknologi KP Jakarta.

Parameter fisik yang diamati adalah suhu pusat tuna loin dengan menggunakan termometer digital (thermolyne). Parameter kimia yang diamati adalah pH (Yunizal et al., 1998), dan TVB menggunakan metode Conway (Yunizal et al., 1998). Selain itu, juga dilakukan analisis proksimat pada tuna loin yang digunakan sebagai sampel pada saat sampel didaratkan baik di miniplant atau pos pendaratan meliputi kadar air (SNI 01-2354.2-2006), kadar abu (SNI 01-2354.1-2006), kadar protein (SNI 01-2354.4-2006) dan kadar lemak (SNI 01-2354.3-2006) (BSN, 2006').

Parameter mikrobiologi yang diamati meliputi angka lempeng total (ALT), Salmonella, dan E. coli. Analisis angka lempeng total (ALT) dilakukan dengan menggunakan media Kit Sansui (Anon., 2010), E. coli dan Salmonela diamati dengan menggunakan media Kit Sanita Kun khusus untuk Salmonella dan E. coli
(Ushiyama \& Iwaki, 2010; Anon., 2010). Koloni yang positif kemudian diverifikasi kembali, untuk $E$. coli ditumbuhkan kembali di media eosin methylene blue agar (EMB) sedangkan untuk Salmonella $s p$ ditumbuhkan di media lysine iron agar (LIA) dan triple sugar iron agar (TSIA).

Uji sensori dilakukan terhadap tuna loin segar maupun matang yang telah dihilangkan kulitnya (skinning) dan dilakukan trimming. Pengamatan dilakukan dengan menggunakan lembar penilaian organoleptik tuna segar untuk sashimi yang mengacu pada SNI 01.2693.1-2006 (BSN, 2006D). Selain itu juga diamati secara deskriptif terhadap parameter yang diamati. Pengujian sensori dilakukan oleh panelis terlatih (6 orang).

\section{Evaluasi sanitasi sarana prasarana pengolahan yang digunakan}

Evaluasi sanitasi sarana dan prasarana yang digunakan untuk proses pengolahan loin dilakukan di perahu dan miniplant. Evaluasi sanitasi dilakukan dengan menganalisis cemaran mikroba yang meliputi angka lempeng total (ALT), E coli dan Salmonella dengan menggunakan metode swab (Fardiaz \& Jenie, 1989). Pengamatan kondisi sanitasi dan higiene di atas kapal dilakukan terhadap meja perahu, stirofoam dan palka. Sedangkan di miniplant dilakukan terhadap meja pengolah, pisau loin, timbangan, es, pekerja dan stirofoam.

\section{Evaluasi implentasi GMP miniplant tuna}

Evauasi implementasi GMP dilakukan untuk menilai kondisi sarana dan prasarana di miniplant yang meliputi beberapa kriteria berdasarkan persyaratan teknis di dalam Kep Men No. 52A/ KEPMEN/2013 tentang Persyaratan Jaminan Mutu dan Keamanan Hasil Perikanan pada Proses Produksi, Pengolahan, dan Distribusi (Kementerian Kelautan dan Perikanan RI, 2013). Di dalam Kep Men tersebut terdapat 19 kriteria dengan total nilai 100 dan masing masing kriteria mempunyai nilai yang berbeda. Penilaian dilakukan dengan menggunakan lembar penilaian dengan mencocokkan kondisi di lapangan dengan kriteria di lembar pengamatan.

\section{HASIL DAN BAHASAN}

\section{Gambaran Umum Penanganan dan Pemrosesan Tuna Loin}

Tuna loin merupakan salah satu komoditi ekspor yang cukup potensial di Ambon baik dalam bentuk beku atau segar untuk sashimi dengan harga yang cukup mahal. Pada umumnya ikan tuna ditangkap 
oleh nelayan kecil dengan menggunakan perahu yang terbuat dari kayu berukuran panjang 7-8 meter dan lebar antara 1-1,5 meter. Perahu tersebut tidak dilengkapi dengan atap maupun palka. Alat tangkap yang digunakan adalah pancing tonda (troll line), dengan hasil tangkapan sebagian besar berupa tuna sirip kuning (yellow fin tuna). Nelayan membawa stirofoam berukuran 40 x $60 \mathrm{~cm}$ yang digunakan untuk membawa es dan menyimpan hasil tangkapannya. Stirofoam yang digunakan umumnya sudah berulang kali digunakan sehingga permukaannya tidak halus, kurang terjaga kebersihannya dan daya insulasinya berkurang. Peralatan lain yang digunakan adalah pemukul kayu, pisau, busa tebal serta plastik untuk membungkus tuna loin.

Ikan tuna yang tertangkap dimatikan dengan memukul kepalanya dengan kayu ketika ikan masih di air, kemudian perdarahan dilakukan dengan menggoyang goyangkan ikan, dan ikan dibiarkan meronta-ronta sekitar 10-15 menit. Tuna hasil tangkapan kemudian diangkat ke atas perahu kemudian ditangani dan diproses menjadi loin di atas kapal. Pertama, ikan dibersihkan dengan menggunakan spons, untuk menghilangkan darah serta kotoran lainnya. Ikan kemudian dipotong kepala dan dikeluarkan isi perutnya dan diproses menjadi 4 loin yaitu 2 loin bagian punggung dan 2 loin bagian perut. Loin kemudian dibersihkan darahnya dengan menggunakan spons kemudian dimasukkan ke dalam plastik khusus untuk tuna. Tuna loin kemudian dies dan dimasukkan ke dalam stirofoam untuk dibawa ke pos atau miniplant tuna loin di darat. Jarak antara fishing ground dan pos pendaratan berkisar antara 45 jam. Dengan penanganan tersebut di atas tuna loin dengan berat lebih dari $4 \mathrm{~kg}$ dapat dipertahankan sebagai grade $A$ untuk sashimi, sehingga akan diperoleh nilai yang lebih tinggi. Namun apabila ikan tuna dengan ukuran yang sama didaratkan dalam bentuk utuh, mutunya tidak dapat dipertahankan sebagai grade A. Hal ini disebabkan karena proses pendinginan yang dilakukan kurang baik, yang menyebabkan suhu pusat tuna masih tinggi ketika sampai di darat sehingga mutu tuna turun menjadi grade yang lebih rendah (Suryaningrum, Purnomo, Ikasari, \& Octavini, 2016).

Ikan tuna biasanya didaratkan di pos pendaratan atau miniplant untuk mendapat penanganan lebih lanjut. Pemilik miniplant kadang bertindak sebagai pedagang perantara atau sebagai pemasok tuna loin segar untuk Unit Pengolah Ikan (UPI) di luar kota Ambon seperti Denpasar atau Jakarta untuk di ekspor ke Jepang. Pos pendaratan tuna biasanya berada di pinggir pantai dengan menggunakan fasilitas seadanya jauh dari standar teknis untuk pengolahan tuna segar yang disyaratkan menurut Kep Men KP No. 52A/
KEPMEN/2013. Akan tetapi beberapa pos pendaratan merupakan kepanjangan tangan dari UPI di Ambon, yang memiliki fasilitas dan sarana pengolahan yang lebih memadai. Miniplantyang digunakan kadang tidak dilengkapi dengan mesin pendingin, sehingga ketika proses skinning, dan trimming yang berlangsung selama kurang dari 15 menit, suhu tuna loin naik sekitar 0,5 $0,6^{\circ} \mathrm{C}$.

Di miniplant tuna loin kemudian ditimbang, dikuliti, dan ditrimming sehingga diperoleh loin bersih (skin less). Sedangkan di pos pendaratan tuna loin hanya dibersihkan kembali untuk menghilangkan kotoran, tulang dan daging coklatnya, kemudian dies kembali. Keesokan harinya tuna loin dikirim ke UPI dan pedagang pengepul yang ada di Ambon dengan menggunakan mobil. Pedagang pengepul selanjutnya memproses tuna loin di miniplant miliknya menjadi tuna loin skin less kemudian dikirim ke luar Kota Ambon. Selanjutnya tuna loin diekspor ke Jepang melalui pihak ke 2 yang mempunyai izin ekspor tuna segar untuk sashimi.

\section{Komposisi Proksimat Tuna Loin}

Hasil analisis proksimat tuna loin segar yang digunakan dalam penelitan ini dapat dilihat pada Tabel 1. Rata-rata kadar air ikan tuna loin dalam penelitian ini berkisar antara 72,05-72,31\%. Kadar air ini tidak jauh berbeda dengan dengan kadar air ikan tuna jenis yellow fin hasil penelitian Wiliam (1986) di dalam Wibowo et al., (2007) yaitu 71-76,76\%.

Rata-rata kadar lemak tuna loin yang didaratkan di Ambon kurang dari 1\% (0,83-0,98\%) tergolong sangat rendah. Hal ini mungkin karena tuna yang dianalisis berasal dari perairan tropis yang umumnya mengandung lemak yang lebih rendah dibandingkan tuna dari perairan dingin (Gang, 2013). Selain itu, kandungan lemak juga dipengaruhi oleh ukuran ikan, kebiasaan makan serta kondisi perairan di daerah penangkapan (Syarif et al., 2012). Tuna berukuran besar dengan berat di atas $90 \mathrm{~kg}$ mempunyai kandungan lemak yang cukup tinggi (Nurbrega, Mendes \& Mendes, 2014). Dalam penelitian ini berat tuna loin yang digunakan berkisar antara 14,1-16,1 $\mathrm{kg} /$ loin, atau setara dengan berat tuna yang berkisar 60-65 kg dan tergolong ukuran sedang. Lemak memegang peran penting dalam menentukan harga tuna loin untuk sashimi. Tuna loin dengan kadar lemak tinggi seperti tuna sirip biru dihargai sangat mahal (Bartram, Garrod, \& Kaneko, 1996). Berdasarkan kadar lemaknya tuna sirip kuning yang ditangkap di Ambon masuk kategori rangking 3. Di Jepang tuna sirip kuning harganya lebih murah dibandingkan tuna sirip biru dan mata besar tetapi lebih mahal dibandingkan tuna albacore (Bartram et al., 1996). Kadar protein tuna sirip kuning yang tertangkap di Ambon tergolong cukup tinggi berkisar antara 24,49- 
Tabel 1. Komposisi proksimat tuna loin segar

Table 1. Proximate composition of fresh tuna loin

\begin{tabular}{lcc}
\hline \multicolumn{1}{c}{ Parameter/Parameters } & $\begin{array}{c}\text { Loin didaratkan di miniplant/ } \\
\text { Loin landed at miniplant }\end{array}$ & $\begin{array}{c}\text { Loin didaratkan di pos pendaratan/ } \\
\text { Loin landed at landing post }\end{array}$ \\
\hline Kadar Air/Moisture content (\%) & $72.31 \pm 1.14$ & $72.05 \pm 0.30$ \\
Kadar Abu/Ash content $(\%)$ & $1.37 \pm 0.07$ & $1.37 \pm 0.00$ \\
Kadar Protein/Protein content $(\%)$ & $26.4 \pm 0.22$ & $24.49 \pm 0.09$ \\
Kadar Lemak/Fat content $(\%)$ & $0.98 \pm 0.38$ & $0.83 \pm 0.53$ \\
\hline
\end{tabular}

$26,40 \%$ sehingga dapat digunakan sebagai asupan protein ikan yang potensial.

\section{Karakteristik Mutu Tuna Loin Hasil Tangkapan selama Penanganan dan Distribusinya}

Untuk mengevaluasi mutu tuna loin hasil tangkapan nelayan kecil di Ambon dilakukan pengamatan ketika tuna loin didaratkan dari perahu, dikemas, dan setelah sampai di tempat tujuan (dengan simulasi). Evaluasi dilakukan terhadap suhu, mutu kimia, mikrobiologi dan sensori. Hasilnya sebagaimana disajikan di dalam Tabel 2.

\section{Suhu tuna loin segar}

Hasil pengamatan suhu yang dilakukan ketika tuna loin didaratkan, dikemas, dan setelah sampai di tempat tujuan dapat dilihat pada Tabel 2. Suhu ketika ikan didaratkan jauh di atas suhu minimum yang disyaratkan untuk tuna loin segar menurut SNI 014103.3-2006 yaitu maksimal $4,4^{\circ} \mathrm{C}$ (BSN, 2006 ${ }^{\mathrm{A}}$ ). Tingginya suhu tuna loin disebabkan karena penanganan di atas perahu yang tidak benar. Hal tersebut dapat dikaitkan dengan kondisi ikan ketika ditangkap dan cara mematikan. Ikan dimatikan dengan cara memukul kepalanya dan dibiarkan meronta-ronta sehingga menyebabkan ikan stres dan terjadi metabolisme glikogen dan menyebabkan suhu tubuh tuna meningkat dalam waktu singkat menjadi 35-40 ${ }^{\circ} \mathrm{C}$ (Goodrick et al., 2002; Syarif et al., 2012; Wibowo et al., 2007), sehingga es yang digunakan tidak mampu untuk menurunkan suhu menjadi $4,4^{\circ} \mathrm{C}$.

Seharusnya ikan didaratkan di dek kapal dan dikondisikan sedemikan rupa sehingga ikan lebih santai kemudian baru dimatikan dengan menusuk

Tabel 2. Kondisi tuna loin segar hasil tangkapan nelayan kecil di Ambon Table 2. Fresh tuna loin condition produced by small scale fishermen in Ambon

\begin{tabular}{|c|c|c|c|c|c|c|}
\hline \multirow{2}{*}{$\begin{array}{l}\text { Parameter/ } \\
\text { Parameters }\end{array}$} & \multicolumn{3}{|c|}{$\begin{array}{l}\text { Loin didaratkan di miniplant/ } \\
\text { Loin landed at miniplant }\end{array}$} & \multicolumn{3}{|c|}{$\begin{array}{l}\text { Loin didaratkan di pos pendaratan/ } \\
\text { Loin landed at landing pos }\end{array}$} \\
\hline & $\begin{array}{l}\text { Saat didaratkan/ } \\
\text { Landed }\end{array}$ & $\begin{array}{c}\text { Saat dikemas/ } \\
\text { Packed }\end{array}$ & $\begin{array}{c}\text { Saat sampai di } \\
\text { tujuan/ } \\
\text { Arrived }\end{array}$ & $\begin{array}{l}\text { Saat didaratkan/ } \\
\text { Landed }\end{array}$ & $\begin{array}{l}\text { Saat dikemas/ } \\
\text { Packed }\end{array}$ & $\begin{array}{c}\text { Saat sampai di } \\
\text { tujuan/ } \\
\text { Arrived }\end{array}$ \\
\hline Suhu/Temp $\left({ }^{\circ} \mathrm{C}\right)$ & $16.30 \pm 1.91$ & $2.16 \pm 0.25$ & $6.00 \pm 0.04$ & $10.56 \pm 1.41$ & $1.73 \pm 0.20$ & $5.26 \pm 0.25$ \\
\hline $\mathrm{pH}$ & $6.13 \pm 0.05$ & $6.03 \pm 0.05$ & $6.06 \pm 0.05$ & $6.03 \pm 0.05$ & $5.96 \pm 0.10$ & $6.00 \pm 0.00$ \\
\hline TVB (Mg N\%) & $14.04 \pm 0.80$ & $14.89 \pm 0.77$ & $17.93 \pm 0.82$ & $13.60 \pm 0.72$ & $13.95 \pm 0.40$ & $14.85 \pm 0.33$ \\
\hline $\begin{array}{l}\text { Total bakteri/Total Plate } \\
\text { Count ( Coloni/g) }\end{array}$ & $2.60 \times 10^{3}$ & $1.20 \times 10^{4}$ & $4.90 \times 10^{4}$ & $2.90 \times 10^{3}$ & $8.70 \times 10^{5}$ & $2.80 \times 10^{6}$ \\
\hline Salmonella & $\begin{array}{l}\text { Negatif/ } \\
\text { Negative }\end{array}$ & $\begin{array}{l}\text { Negatif/ } \\
\text { Negative }\end{array}$ & $\begin{array}{l}\text { Negatif/ } \\
\text { Negative }\end{array}$ & $\begin{array}{l}\text { Negatif/ } \\
\text { Negative }\end{array}$ & $\begin{array}{l}\text { Negatif/ } \\
\text { Negative }\end{array}$ & $\begin{array}{l}\text { Negatif/ } \\
\text { Negative }\end{array}$ \\
\hline E coli & $\begin{array}{l}\text { Negatif/ } \\
\text { Negative }\end{array}$ & $\begin{array}{l}\text { Negatif/ } \\
\text { Negative }\end{array}$ & $\begin{array}{l}\text { Negatif/ } \\
\text { Negative }\end{array}$ & $\begin{array}{l}\text { Negatif/ } \\
\text { Negative }\end{array}$ & $\begin{array}{l}\text { Negatif/ } \\
\text { Negative }\end{array}$ & $\begin{array}{l}\text { Negatif/ } \\
\text { Negative }\end{array}$ \\
\hline Colif orm (MDN/mL) & 13.00 & 31.00 & 17.00 & 2.00 & 12.00 & 1.00 \\
\hline Kenampakan/Appearance & $8.00 \pm 0.00$ & $7.67 \pm 0.50$ & $7.50 \pm 0.50$ & $8.00 \pm 0.00$ & $7.67 \pm 0.50$ & $7.50 \pm 0.50$ \\
\hline Tekstur/ Texsture & $8.60 \pm 0.51$ & $8.60 \pm 0.50$ & $7.50 \pm 0.54$ & $9.00 \pm 0.00$ & $9.00 \pm 0.50$ & $7.83 \pm 0.50$ \\
\hline Bau/Odor & $9.00 \pm 0.00$ & $9.00 \pm 0.00$ & $8.83 \pm 0.40$ & $9.00 \pm 0.00$ & $8.83 \pm 0.40$ & $8.50 \pm 0.54$ \\
\hline Rasa/Taste & $9.00 \pm 0.00$ & $8.33 \pm 0.50$ & $7.66 \pm 0.50$ & $9.00 \pm 0.00$ & $7.67 \pm 0.50$ & $7.30 \pm 0.50$ \\
\hline
\end{tabular}


ubun-ubunnya menggunakan spike pada sudut $45^{\circ} \mathrm{C}$ sambil ditekan ke dalam sampai mencapai rongga otak ( Irianto, 2008; Wibowo et al., 2007). Dengan cara demikian kenaikan suhu akibat metabolisme glikogen tidak terjadi (Cramer, Nakamura, Dizon, \& Ikehara, 1981). Setelah ikan dimatikan kemudian dilakukan pendarahan dengan cara memotong saluran darah pada kedua sisi tubuh di sepanjang sirip pektoral, sehingga darah keluar dengan sempurna (Irianto, 2008). Namun karena ukuran perahu yang sangat kecil cara mematikan dan pendarahan yang sesuai dengan prosedur sulit dilakukan, dan ketika tuna ditangani dan diproses menjadi loin kemungkinan suhu tubuhnya masih tinggi akibat terjadinya metabolisme glikogen.

Untuk mendinginkan tuna loin, nelayan menggunakan es curah, sehingga penurunan suhunya lambat dibandingkan dengan slurry es. Apabila suhu tuna loin di atas $30^{\circ} \mathrm{C}$ maka dibutuhkan waktu yang lama untuk menurunkan suhu menjadi $4,4^{\circ} \mathrm{C}$. Hasil penelitian terhadap ikan haddock yang disiangi, penurunan suhu menjadi $0^{\circ} \mathrm{C}$, dengan menggunakan es curah membutuhkan waktu 4,5 jam, sedangkan jika menggunakan slurry ice suhu pusat ikan dapat mencapai $0^{\circ} \mathrm{C}$ dengan waktu kurang dari 1 jam (Gang, 2013). Hal ini disebabkan karena slurry ice menghasilkan suhu pendinginan yang lebih cepat, karena mempunyai energi untuk perpindahan panas lebih besar dibandingkan dengan es curah (Zhang, Deng, Bao, \& Chen, 2015). Namun untuk menurunkan suhu tuna loin menjadi kurang dari $4,4^{\circ} \mathrm{C}$, banyak faktor yang mempengaruhi antara lain tingginya suhu lingkungan di laut. Kondisi tersebut juga diperburuk karena sarana dan prasarana yang digunakan tidak mendukung untuk mendinginkan tuna loin seperti perahu yang tidak dilengkapi dengan atap serta stirofoam yang digunakan memiliki daya insulasi rendah. Faktor lain yang mempengaruhi adalah goncangan kapal yang dapat menimbulkan panas, sehingga penggunaan es menjadi tidak efektif. Seharusnya perpindahan panas dari es digunakan untuk menurunkan suhu tuna loin, tetapi panas tersebut juga digunakan untuk menurunkan suhu ruang (Supriyanto, 2011). Sebetulnya es yang dibawa oleh nelayan sudah lebih dari cukup yaitu sebanyak 2 balok $(100 \mathrm{~kg})$. Pada pendinginan ikan dengan es, panas berpindah dari ikan yang lebih panas menuju es, ikan menjadi dingin dan es meleleh. Jika diasumsikan bahwa tuna yang tertangkap seberat $60 \mathrm{~kg}$ dan suhu awal tuna loin adalah $30^{\circ} \mathrm{C}$ dan suhu dingin yang diinginkan adalah $0{ }^{\circ} \mathrm{C}$ maka berdasarkan rumus panas yang dilepaskan = berat ikan $\mathrm{x}$ perbedaan suhu x panas spesifik ikan $=60 \mathrm{~kg} \times\left(30-0^{\circ} \mathrm{C}\right) \times 0,84=$ 1512 kilo kalori. Sementara es menyerap 80 kilokalori per-kg es yang meleleh, maka berat es yang dibutuhkan untuk mendinginkan ikan menjadi $0{ }^{\circ} \mathrm{C}$ adalah $1512 / 80 \mathrm{~kg}=18,9 \mathrm{~kg}$ es, dibulatkan menjadi $19 \mathrm{~kg}$ (Ganis, 2013). Namun karena kondisi lingkungan dan fasilitas yang tidak memenuhi, syarat energi yang seharusnya digunakan untuk menurunkan suhu tuna loin digunakan untuk mendinginkan udara sekitarnya, akibatnya suhu $4,4^{\circ} \mathrm{C}$ tidak tercapai ketika tuna loin didaratkan.

Suhu ikan yang diharapkan agar mutu dan keamanan pangannya terjamin, adalah suhu dengan kisaran $0-4^{\circ} \mathrm{C}$ (Gang, 2013). Pada kisaran suhu tersebut pertumbuhan sebagian besar bakteri dapat dicegah. Demikian juga aktivitas bakteri pembentuk histamin yang umumnya dibentuk pada suhu tinggi. Tuna merupakan ikan golongan scombroid yang biasanya memiliki kandungan histidin dengan level tinggi (Kalantari, Behfar, Nazari, Kalatari, \& Hosseini, 2015). Jika kondisi penyimpanan tidak dapat mengontrol pertumbuhan bakteri maka bakteri pembentuk histamin yang memiliki enzim histidine dekarboksilase yang akan mengubah histidin bebas menjadi histamin akan terus berkembang (Mc Lauchin, Little, Grant, \& Mithan, 2005). Pendinginan cepat setelah ikan mati merupakan tindakan yang sangat penting dalam strategi mencegah pembentukan scombrotoxin (histamin). Histamin tidak akan terbentuk bila ikan selalu disimpan pada suhu di bawah $5^{\circ} \mathrm{C}$ (Huss, 1988).

Pada saat akan dikemas suhu tuna berada pada kisaran suhu tuna segar untuk tuna sashimi (Tabel 2) yaitu berkisar antara $1,7 \pm 0,2-2,2 \pm 0,3$, namun suhu ideal untuk sashimi adalah $0^{\circ} \mathrm{C}$, atau suhu di sekitar suhu leleh es. Pada suhu $0^{\circ} \mathrm{C}$, kesegaran dan kualitas ikan dapat dipertahankan lebih lama (Quang, 2005). Oleh karena itu sebelum dikirim sebaiknya tuna loin didinginkan di bawah $0^{\circ} \mathrm{C}$, untuk mempertahankan mutu produk tetap segar dan membuat produk tidak sensitif terhadap perubahan selama transportasi (Mai et al., 2012; Martinsdottir et al., 2010).

Pengamatan suhu ketika tuna loin sampai di tempat tujuan (Tabel 2) menunjukkan bahwa rata-rata suhu tuna loin 5,3 $\pm 0,3-6,0 \pm 0,0$ sedikit lebih tinggi dari suhu pusat ikan tuna segar untuk sashimi yang disyaratkan oleh SNI 01-4103.3-2006 (BSN, 2006) yaitu maksimal $4,4^{\circ} \mathrm{C}$. Suhu ikan di atas $5^{\circ} \mathrm{C}$ merupakan suhu kritis untuk pembusukan ikan, karena hampir semua mikroorganisme dapat tumbuh pada suhu 5-60 ${ }^{\circ} \mathrm{C}$ (Chong, 2012). Kenaikan suhu tuna loin sangat dipengaruhi oleh suhu luar selama pengiriman dan transportasi ke luar Kota Ambon yaitu 2 jam pada suhu kamar (suhu 29,2 ${ }^{\circ} \mathrm{C}$ ), 3 jam dalam pernerbangan $\left(19,4-19,7^{\circ} \mathrm{C}\right)$, kemudian suhu kamar 1,5 jam. Suhu simulasi selama penerbangan tidak jauh berbeda dengan suhu ambang atas suhu bagasi pesawat yaitu berkisar $15-20^{\circ} \mathrm{C}$ (Boue, 2015; James, James, \& Evan, 2006). 
Dalam penelitian ini ikan tuna dikemas dengan menggunakan kotak stirofoam merk garuda (original) yang mempunyai permeabilitas yang tinggi, sehingga ikan tidak mudah mengalami kenaikan suhu yang relatif singkat (Margerisson, 2012). Dalam penelitian ini es yang digunakan untuk menjaga suhu ikan dalam kemasan hanya mencair $10 \%$ dari berat es semula, akan tetapi es batu yang ditambahkan belum mampu menurunkan suhu di dalam kemasan stirofoam sehingga kurang dari $5^{\circ} \mathrm{C}$. Penggunaan es kering kemungkinan lebih efektif untuk mempertahankan suhu tuna loin dibandingkan dengan es biasa. Hasil penelitian Bao, Arroson, dan lorarinsdottir (2007) terhadap filet ikan Salmon (Salvellinus alpinus) yang dikemas dengan kotak stirofoam, untuk mempertahankan suhu dalam kemasan digunakan es kering dan es biasa. Hasil penelitiannya menunjukkan bahwa suhu dalam kotak stirofoam yang menggunakan es kering dapat mencapai $-0,5^{\circ} \mathrm{C}$ dalam waktu 15 menit, sedangkan untuk es biasa dibutuhkan waktu 78 jam.

\section{$\mathrm{pH}$ tuna loin segar}

Hasil pengamatan $\mathrm{pH}$ yang dilakukan terhadap tuna loin segar ketika didaratkan, dikemas dan setelah sampai di tempat pengiriman sedikit agak asam, berkisar dari 5,96 hingga 6,13 (Tabel 2). Nilai pH tuna loin sedikit menurun ketika tuna loin dikemas, pada tuna loin yang didaratkan di miniplant yang dies semalam (Tabel 2). Penurunan nilai $\mathrm{pH}$ ini kemungkinan disebabkan masih terbentuknya asam laktat secara endogen yang berpengaruh terhadap menurunnya nilai $\mathrm{pH}$ daging tuna loin yang dihasilkan (Huss, 1988). Nilai pH sedikit meningkat ketika sampai di tempat tujuan. Tuna loin yang didaratkan di miniplant (dies semalam) pHnya meningkat dari $6,03 \pm 0,05$ menjadi $6,06 \pm 0.05$. Pada tuna loin yang didaratkan di pos pendaratan (di es 2 malam) $\mathrm{pH}$ meningkat dari 5,96 $\pm 0,11$ menjadi $6,0 \pm 0,0$. Kenaikan nilai $\mathrm{pH}$ disebabkan karena pembentukan senyawa yang bersifat alkali seperti amonia dan trimetil amin sebagai hasil aktivitas bakteri selama proses pembusukan (Ozyurt, Kuley, Ozkutuk, \& Ozogul, 2009). Hal ini dapat dikaitkan dengan meningkatnya kandungan jumlah bakteri selama penanganan dan distribusi seperti terlihat pada Tabel 2.

Hasil pengamatan nilai $\mathrm{pH}$ ini tidak jauh berbeda dengan $\mathrm{pH}$ ikan tuna sirip kuning yang baru ditangkap hasil penelitian lain (Susanto, Agustini, Ritanto, Dewi, \& Swastawatim, 2011; Widiastuti, Putro, Fardiaz, Trilaksani, \& Inaoko, 2012) yang berkisar antara 5,856,01 . Nilai $\mathrm{pH}$ daging ikan ketika masih hidup pada umumnya mendekati 7 , tetapi setelah kematian, $\mathrm{pH}$ ikan berkisar antara 6 sampai 7 tergantung spesies, proses penangkapan, kondisi biologi, musim, dan cara mematikan ikan (Ozogul, 2010). Nilai pH ikan tuna loin dikatakan baik apabila nilainya di atas 5,7 (Watson, Bourke, \& Brill, 1988). Rendahnya pH daging tuna dapat mengindikasikan tingkat stress tuna akibat tingginya akumulasi asam laktat di dalam daging tuna (Jinadasa, Galhena, \& Liyanage, 2015).

Saat ikan didaratkan, nilai $\mathrm{pH}$ dapat dihubungkan dengan kondisi stress sebelum ikan mati. Stress yang berkepanjangan sebelum ikan dimatikan mengakibatkan terjadi proses metabolisme dalam jaringan dan menghasilkan asam laktat yang terakumulasi di dalam darah, sehingga menyebabkan nilai pH ikan tuna segar menjadi rendah (Goodrick, et al, 2002; Wibowo et al., 2007). Namun demikian pH ikan tuna hasil penelitian (Tabel 2) sedikit lebih baik dibandingkan dengan nilai $\mathrm{pH}$ tuna sirip kuning yang baru ditangkap di Sri Lanka yaitu 5,74 $\pm 0,15$ yang menunjukkan tingginya akumulasi asam laktat di dalam daging ikan tuna (Jinadasa et al., 2015). Menurut Cramer et al., (1981), penanganan yang kurang baik akan menyebabkan rendahnya nilai $\mathrm{pH}$ yang berakibat menurunnya mutu daging tuna loin segar yang dihasilkan. Daging tuna yang mempunyai nilai pH berkisar antara 5,4-5,6 digolongkan sebagai tuna mutu rendah. Dalam penelitian ini $\mathrm{pH}$ ikan tuna loin yang didaratkan lebih dari 6 sehingga dapat digolongkan sebagai tuna loin yang bermutu baik. Jika $\mathrm{pH}$ ikan tuna rendah serta suhu daging tuna tinggi akan menstimulasi kerja enzim katepsin yang bersifat proteolisis. Enzim tersebut akan memecah aktin dan miosin dan menyebabkan terjadinya denaturasi protein yang menyebabkan warna daging menjadi matang (Watson et al., 1988). Demikian juga nilai pH akan berpengaruh terhadap tekstur daging ikan karena rusaknya jaringan penghubung akibat perubahan $\mathrm{pH}$ setelah post mortem (Jinadasa et al., 2015).

Menurut Maeda et al. (2014) penanganan di atas kapal sangat penting untuk memperoleh ikan segar dengan mutu tinggi. Ketika ikan ditangkap ikan harus dibuat dalam keadaan setenang mungkin sebelum dimatikan. Pada cara mematikan ikan dengan kondisi ikan tenang akan diperoleh ikan yang bermutu tinggi, dengan $\mathrm{pH}$ dan kandungan ATP tinggi, serta kandungan asam laktat rendah. Penelitian terhadap ikan layang yang baru ditangkap dengan jaring, kandungan ATP dan asam laktatnya berturut-turut sebesar $4,1 \mu \mathrm{mol} / \mathrm{g}$ dan $34,5 \mu \mathrm{mol} / \mathrm{g}$. Setelah ikan ditenangkan kandungan ATPnya meningkat menjadi $8,6 \mu \mathrm{mol} / \mathrm{g}$ dan asam laktatnya turun menjadi $4,2 \mu \mathrm{mol} /$ $\mathrm{g}$, yang berpengaruh terhadap meningkatnya nilai $\mathrm{pH}$ ikan (Fukusima, Maeda, \& Fukuda, 2012).

\section{Kadar Total Volatile Base (TVB)}

Total Volatile Base (TVB) merupakan salah satu indikator biokimiawi yang umum digunakan untuk menentukan proses kemunduran mutu ikan, yaitu 
seberapa jauh kemunduran mutu ikan telah terjadi. Dalam hal ini, TVB secara tidak langsung mengindikasikan kesegaran ikan terutama jika dikaitkan dengan sifat sensori dan jumlah bakteri pada ikan (Amegovu, Serunjogi, Ogwok, \& Makokha, 2012). Pengamatan terhadap kandungan TVB menunjukkan bahwa ikan tuna yang didaratkan, ketika dikemas, dan setelah sampai di tempat tujuan belum menunjukkan terjadinya kemunduran mutunya sehingga masih tergolong segar meskipun tidak termasuk dalam mutu prima lagi (TVB < 10mgN\%) (Tabel 2). Berdasarkan nilai TVBnya, tingkat kesegaran ikan (termasuk tuna) dikelompokkan menjadi 4 yaitu (1) ikan sangat segar (prima) dengan kadar TVB $<10$ mgN\%, (2) ikan segar dengan kadar TVB 10-20 mgN\%, (3) ikan masih berada pada garis batas kesegaran yang masih dapat dikonsumsi dengan kadar TVB 20-30 mgN\%, dan (4) ikan busuk yang tidak layak untuk dikonsumsi dengan kadar TVB > 30 mgN\% (Dalgaars, 2000 dalam Jinadasa, 2014). Berdasarkan mutunya, hasil penelitian Hardiana (2009) menunjukkan bahwa tuna loin grade A mempunyai kadar TVB 8,42 $\pm 0,39$ mgN\%, grade $B$ kadar TVB

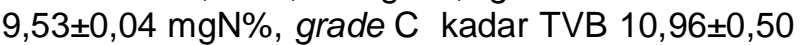
$\mathrm{mgN} \%$, dan grade D kadar TVB 12,06 $\pm 0,86 \mathrm{mgN} \%$. Tingginya kandungan TVB tersebut dipicu oleh suhu tuna loin yang cukup tinggi sebelum didaratkan di mana kecepatan pembusukan ikan tuna bisa 4 kali lipat jika dibandingkan dengan tuna yang disimpan pada suhu $0{ }^{\circ} \mathrm{C}$, dan menjadi 30 kali lipat jika suhu di dalam daging ikan sebesar $32^{\circ} \mathrm{C}$ (Anon, 1995). Suhu tuna ketika didaratkan berkisar $10,56-16,53^{\circ} \mathrm{C}$ (Tabel 2). Suhu tersebut merupakan suhu optimum untuk pertumbuhan bakteri psikrofilik yang bersifat pembusuk seperti Pseudomonas, Alteromonas, Shewanella, Moraxella, Actinobacter, Vibrio, Flavobacteria, dan Cytophago yang menghasilkan senyawa volatil seperti tri-metiliamin dan amonia yang berasal dari pemecahan asam asam amino (Gang, 2013).

Kandungan TVB pada tuna dalam penelitian ini masih lebih baik dibandingkan dengan kandungan TVB ikan tuna sirip kuning utuh yang didaratkan di Sri Lanka (Jinadasa et al., 2015) yaitu sebesar 26,63 $\pm 2,41$ $\mathrm{mgN} \%$. Demikian juga ikan tuna albacore utuh yang didaratkan di Brazil yang kandungan TVBnya di atas $30 \mathrm{mgN} \%$, yang menunjukkan bahwa ikan sudah tidak segar lagi. Dengan demikian dapat dikatakan bahwa berdasarkan kandungan TVB ini, tuna yang didaratkan dalam bentuk loin lebih baik dibandingkan dengan tuna yang didaratkan dalam bentuk utuh (gelondongan).

Ketika sampai di tempat pengiriman kandungan TVB pada loin tuna sedikit meningkat jika dibandingkan ketika didaratkan. Pada tuna loin yang didaratkan di miniplant (dies semalam) kandungan TVB nya sedikit

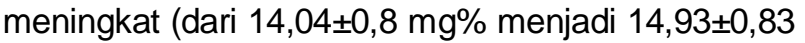

$\mathrm{mg} \%$ ). Sedangkan pada tuna loin yang didaratkan di pos pendaratan (dies 2 malam) kandungan TVB meningkat (dari 13,6 $\pm 0,72 \mathrm{mgN} \%$ menjadi 14,85 $\pm 0,33$ $\mathrm{mgN} \%$ ) (Tabel 2).

TVB merupakan senyawa amina biogenik yang merupakan gabungan dari amonia $\left(\mathrm{NH}_{3}\right)$, Dimethyl Amine (DMA) dan Trimethyl Amine (TMA) yang biasanya digunakan sebagai indikator kemunduran mutu ikan (Wu \& Bechiel, 2008). Kenaikan kandungan TVB sejalan dengan meningkatnya kandungan TMA sebagai hasil reduksi trimetil amine oksida (TMAO) oleh enzim dehydrogenase dan aktivitas bakteri pembusuk (Jinadasa, 2014). Pada proses pembusukan ikan, mikroorganisme memanfaatkan atom oksigen yang disumbangkan oleh TMAO dalam kondisi anaerob dan mengakibatkan pembentukan TMA (Adams \& Moss, 2008 dalam Murtini, Riyanti, Priyanto, \& Hermana, 2014). Namun demikian kandungan TVB masih di bawah 20 mgN\% yang menunjukkan bahwa kemunduran mutu tuna masih di tahap awal dan dapat dikatagorikan sebagai segar (Dalgaars, 2000 dalam Jinadasa, 2014).

\section{Cemaran mikroba}

Tuna untuk sashimi harus aman, bebas dari resiko kesehatan seperti adanya infeksi oleh bakteri pathogen dan parasit (Muscolino et al., 2014). Hasil analisis cemaran mikroba patogen terhadap E. coli dan Salmonella sp. menunjukkan hasil yang negatif. Hasil ini sama dengan hasil penelitian mengenai penanganan dan pengolahan ikan tuna loin segar di atas perahu hingga pada tingkat suplier di desa Asilulu, Ambon-Maluku yang dilakukan oleh Siregar et al., (2014). Bakteri patogen merupakan bakteri yang dapat menyebabkan terjadinya penyakit yang seharusnya tidak boleh ada pada tuna segar untuk sashimi (BSN, 2009).

Hasil analisis terhadap angka lempeng total (ALT) menunjukkan bahwa rata-rata ALT ketika ikan didaratkan sebesar 2,6 × 103 koloni/g. Jumlah ini lebih tinggi dibandingkan dengan hasil penelitian Widiastuti dan Putro (2010) terhadap tuna yang didaratkan di Pelabuhan Ratu yang ditangkap, disiangi dan disimpan pada palka yaitu sebesar $10^{2} \mathrm{koloni} / \mathrm{g}$. Tingginya kandungan bakteri tersebut disebabkan karena meja pada kapal yang digunakan proses loin tuna kurang saniter dengan kandungan bakteri sebesar 4,7 x $10^{6}$ koloni/sel serta bakteri Coliform sebesar 235 MPN/ $\mathrm{mL}$, sehingga kemungkinan tuna tercemar dari meja kapal yang digunakan sangat besar (Tabel 4).

Ketika dikemas angka lempeng total (ALT) tuna loin yang didaratkan di pos pendaratan (dies 2 malam) meningkat lebih cepat dibandingkan dengan tuna loin yang didaratkan di miniplant. Peningkatan jumlah bakteri cukup tinggi terjadi pada tuna loin yang 
didaratkan di pos pendaratan (dies 2 malam) setelah sampai di tempat tujuan. Kandungan jumlah bakteri tersebut meningkat dari 2,9 × $10^{3} \mathrm{koloni} / \mathrm{g}$ menjadi $2,87 \times 10^{5} \mathrm{koloni} / \mathrm{g}$. Angka ini melebihi dari standar BSN untuk ALT tuna segar untuk sashimi (BSN, 2006A) dan European Commision (EC Reg No 2073/2005) (Muscolino et al., 2014). Tingginya jumlah bakteri tersebut dipicu oleh meningkatnya suhu selama transportasi dari sekitar $1,73-2,16^{\circ} \mathrm{C}$ menjadi 5,76$6,01^{\circ} \mathrm{C}$. Pada suhu rendah $\left(0-5^{\circ} \mathrm{C}\right)$ bakteri psikrofilik aerob yang bersifat pembusuk seperti Pseudomonas, dan Shewanella putrifaciens dapat berkembang dengan baik (Quang, 2005). Kandungan jumlah bakteri coliform berkisar antara 1 - 31 MPN/g. Jumlah ini cukup tinggi jika dibandingkan dengan standar coliform untuk tuna loin, yaitu < 3 MPN/g (SNI 7530.1.2009) (BSN, 2009). Tingginya coliform kemungkinan dapat terkontaminasi dari sarana dan prasarana yang digunakan seperti terlihat pada Tabel 4.

\section{Sensori tuna loin segar}

Penilaian karakteristik sensori tuna loin segar terhadap kenampakan, tekstur, bau dan rasa dapat dilihat pada Tabel 2 sedangkan pengamatan secara deskritif dapat dilihat pada Tabel 3.

\section{Kenampakan}

Secara sensoris, kenampakan tuna loin yang didaratkan secara deskritif menunjukkan adanya lapisan pelangi tipis (Tabel 3). Adanya lapisan pelangi ini disebabkan karena kondisi ikan yang stress (Watson et al., 1988) ketika ditangkap sehingga suhu ikan meningkat. Dalam kondisi stres, ikan tuna akan mengekskresi senyawa norepinephrine dan epinephrine dalam darah yang menyebabkan meningkatnya kadar catechol amines dalam sirkulasi darah menjadi 10-200 kali. Kondisi tersebut memicu terjadinya fosforilasi troponin yang terlihat sebagai pelangi pada permukaan daging (Watson et al., 1988).

Nilai sensori kenampakan menurun saat tuna dikemas dan ketika tiba di tempat tujuan (Tabel 2). Saat sampai di tempat tujuan warna daging menjadi merah tua dengan lapisan pelangi yang semakin jelas (Tabel 3). Pengolah tuna loin di miniplant menilai grade tuna loin turun dari grade A menjadi B. Perubahan warna tersebut disebabkan warna merah daging tuna tidak stabil pada suhu $0^{\circ} \mathrm{C}$, sensitif terhadap suhu rendah, dan oksidasi (Bartram et al., 1996). Pada tuna loin yang diamati tidak tampak adanya bercak putih yang menjadi indikasi adanya parasit dalam tubuh ikan.

\section{Tekstur}

Pengamatan secara deskritif untuk tuna loin yang didaratkan di miniplant (Tabel 3) menunjukkan adanya pembengkakan otot yang berpengaruh terhadap menurunnya elastisitas tekstur tuna loin yang dihasilkan. Sedangkan terhadap tuna yang didaratkan di pos kemudian baru dikirim ke miniplant, panelis memberikan nilai 9 (Tabel 2) yang mengacu pada tekstur tuna loin yang bersifat elastis, padat dan kompak. Perbedaan tekstur ini kemungkinan disebabkan karena proses kematian yang berbeda dari 2 sampel yang digunakan. Ikan yang didaratkan di miniplant kemungkinan mengalami stres yang berkepanjangan sehingga menyebabkan terjadinya pembengkakan otot daging yang dihasilkan (Cramer et al., 1981).

Ketika tuna loin dikemas, panelis memberikan nilai tekstur yang tidak berubah (Tabel 2) yang menunjukkan bahwa pengesan yang dilakukan selama semalam (miniplant) atau 2 malam (pos pendaratan) tidak berpengaruh terhadap tekstur tuna loin. Panelis memberikan nilai yang menurun ketika tuna loin sampai di tempat tujuan karena tekstur tuna loin menjadi kurang kompak (Tabel 2). Walaupun tuna loin dalam penelitian ini telah dikemas vakum untuk mempertahankan struktur daging agar tidak mengalami perubahan selama pengiriman (Masniyom, 2008), tetapi pengemasan vakum yang dilakukan tampaknya tidak berpengaruh terhadap perubahan tekstur daging tuna loin. Menurut Cramer et al. (1981) penurunan tekstur disebabkan karena terjadinya pembengkakan akibat ikan stres sebelum dimatikan sehingga menyebabkan bakteri lebih mudah masuk ke dalam jaringan. Menurunnya nilai tekstur daging tuna dapat dikaitkan dengan hilangnya pita $Z$ pada sel otot dengan terlepasnya $\alpha$-aktinin yang memisahkan kompleks aktomiosin yang menyebabkan tekstur menjadi kurang elastis (Tanako \& Osako, 2008). Sedangkan menurut Huss (1988), menurunnya tekstur disebabkan oleh rendahnya $\mathrm{pH}$ tuna loin $(5,96-6,00)$ yang akan menstimulasi aktivitas enzim katepsin yang bersifat proteolisis dan akan berpengaruh terhadap tekstur daging tuna karena pecahnya jaringan penghubung. Namun demikian, berdasarkan nilai sensori, teksturnya $(7,00-7,67)$ tuna loin masih termasuk kategori segar menurut SNI 01.2346-2006 (BSN, 2006 ${ }^{\mathrm{D}}$ ).

\section{$\mathrm{Bau}$}

Ikan laut yang segar hampir tidak mengeluarkan bau, karena hanya mengandung sedikit senyawa volatil. Segera setelah penangkapan, daging tuna memiliki bau karakteristik dengan bau sangat segar dan spesifik jenis (Jinadasa, 2014). Ketika tuna di daratkan di miniplant atau di pos pendaratan, bau ikan masih sangat segar dengan spesifik jenis (nilai sensori bau 9). Nilai sensori bau tidak berubah ketika tuna loin dikemas, tetapi sedikit menurun ketika sampai 
ditempat tujuan (Tabel 2). Ketika sampai di tempat pengiriman, bau ikan yang sangat segar tidak tercium sehingga menyebabkan penilaian panelis terhadap bau sedikit menurun. Namun demikian, belum ada perubahan ke arah bau yang tidak diinginkan karena pemecahan protein menjadi senyawa seperti $\mathrm{H}_{2} \mathrm{~S}$, indol, dan skatol yang menyebabkan bau kurang segar (Tanaka \& Osako, 2009). Nilai sensori bau tuna loin setelah dikirim ke luar Kota Ambon baik tuna loin yang didaratkan di miniplant maupun di pos pendaratan masih di atas nilai 8 atau tergolong segar menurut SNI 01.2346-2006 (BSN, 2006)

\section{Rasa}

Pengamatan terhadap rasa tuna loin ketika didaratkan, dikemas dan setelah sampai di tempat

Tabel 3.Pengamatan sensori tuna loin secara deskriptif Table 3. Sensori evaluation of tuna loin

\begin{tabular}{|c|c|c|}
\hline $\begin{array}{l}\text { Saat pendaratan/ } \\
\text { Landing stage }\end{array}$ & $\begin{array}{l}\text { Saat pengemasan/ } \\
\text { Packing stage }\end{array}$ & $\begin{array}{c}\text { Saat tiba di tem pat tujuan/ } \\
\text { Arriving stage }\end{array}$ \\
\hline \multicolumn{3}{|l|}{ Kenampakan/Appearance } \\
\hline $\begin{array}{l}\text { Miniplant : Warna merah cerah, serat daging } \\
\text { merekat kuat, terlihat adanya pelangi tipis pada } \\
\text { permukaan tuna loin menyerupai lapisan minyak } \\
\text { berw arna w arni, tidak terlihat adanya yake/ } \\
\text { Miniplant : red bright color meat, strongly tight } \\
\text { tissue muscle, thin rainbow layer on the loin } \\
\text { surface, no yake identified. }\end{array}$ & $\begin{array}{l}\text { Miniplant: Daging berw arna merah } \\
\text { cerah, serat daging merekat kuat, } \\
\text { lapisan pelangi pada permukaan loin } \\
\text { semakin terlihat jelas/Miniplant : red } \\
\text { bright color meat, strongly tight } \\
\text { tissue muscle, a clear rainbow layer } \\
\text { on the loin surface }\end{array}$ & $\begin{array}{l}\text { Miniplant: Warna daging ikan tuna } \\
\text { menjadi merah tua, serat daging masih } \\
\text { merekat kuat, lapisan pelangi semakin } \\
\text { jelas terlihat/Miniplant : dark red color } \\
\text { meat, strongly tight tissue muscle, a } \\
\text { clear rainbow layer on the surface. }\end{array}$ \\
\hline $\begin{array}{l}\text { Pos: Warna daging merah cerah, serat daging } \\
\text { merekat kuat, terlihat adanya pelangi tipis pada } \\
\text { permukaan daging, tidak terlihat adanya } \\
\text { yake/Post: red bright color meat, strongly tight } \\
\text { tissue muscle, thin rainbow layer on the loin } \\
\text { surface, no yake indentified. }\end{array}$ & $\begin{array}{l}\text { Pos : Daging berw arna merah cerah, } \\
\text { serat daging merekat kuat, lapisan } \\
\text { pelangi semakin jelas/Post : red } \\
\text { bright color meat, strongly tight } \\
\text { tissue muscle, a clear rainbow layer } \\
\text { on the loin surface }\end{array}$ & $\begin{array}{l}\text { Pos : Warna daging menjadi merah } \\
\text { tua, serat daging masih merekat kuat, } \\
\text { lapisan pelangi semakin jelas/Post: } \\
\text { dark red color meat, strongly tight } \\
\text { tissue muscle, a clear rainbow layer } \\
\text { on the surface. }\end{array}$ \\
\hline \multicolumn{3}{|l|}{ Tekstur/Texture } \\
\hline $\begin{array}{l}\text { Miniplant: tekstur elastis, padat sedikit kurang } \\
\text { kompak, terlihat adanya pembengkakan } \\
\text { otot./Miniplant: elastic, solid but less compact } \\
\text { texture; muscle swelling identified }\end{array}$ & $\begin{array}{l}\text { Miniplant : Tekstur masih elastis, } \\
\text { padat sedikit kurang kompak, terlihat } \\
\text { adanya pembengkakan otot/Miniplant } \\
\text { : elastic, solid, but less compact } \\
\text { texture; muscle swelling identified }\end{array}$ & $\begin{array}{l}\text { Miniplant : Tekstur daging masih } \\
\text { elastis, antar jaringan otot masih erat, } \\
\text { tetapi kurang kompak namun tidak } \\
\text { pecah/Minipant : elastic texture; tight } \\
\text { but less compact muscle tissue; the } \\
\text { tissue still intact. }\end{array}$ \\
\hline $\begin{array}{l}\text { Pos: tekstur elastis, padat dan kompak, tidak } \\
\text { nampak adanya pembengkakan otot/ Post: } \\
\text { elastic, solid, and compact texture; no muscle } \\
\text { swelling identified. }\end{array}$ & $\begin{array}{l}\text { Pos : Tekstur elastis, padat dan } \\
\text { kompak. Tidak nampak adanya } \\
\text { pembengkakan otot/Post : elastic, } \\
\text { solid, and compact texture; no } \\
\text { muscle swelling identified }\end{array}$ & $\begin{array}{l}\text { Pos : Tekstur daging masih elastis, } \\
\text { padat, sedikit kurang kurang } \\
\text { kompak/Post: elastic, solid, but less } \\
\text { compact texture. }\end{array}$ \\
\hline \multicolumn{3}{|l|}{ Bau/Odor } \\
\hline $\begin{array}{l}\text { Miniplant: Bau tuna loin sangat segar khas } \\
\text { tuna loin/Miniplant: specific very fresh tuna } \\
\text { loin odor }\end{array}$ & $\begin{array}{l}\text { Miniplant : Bau tuna loin masih } \\
\text { sangat segar dengan spesifik tuna } \\
\text { loin/Miniplant: spesific very fresh } \\
\text { tuna loin odor }\end{array}$ & $\begin{array}{l}\text { Miniplant : Bau ikan segar. spesifik } \\
\text { tuna loin/Miniplant : specific fresh tuna } \\
\text { loin odor }\end{array}$ \\
\hline $\begin{array}{l}\text { Pos: Bau tuna loin sangat segar khas tuna } \\
\text { loin/Post : spesific very fresh tuna loin odor }\end{array}$ & $\begin{array}{l}\text { Pos : Bau lkan segar spesifik tuna } \\
\text { loin/Post : spesific fresh tuna loin } \\
\text { odor }\end{array}$ & $\begin{array}{l}\text { Pos : Bau lkan segar spesifik tuna } \\
\text { loin/Post : spesific fresh tuna loin } \\
\text { odor }\end{array}$ \\
\hline \multicolumn{3}{|l|}{ Rasa/Taste } \\
\hline $\begin{array}{l}\text { Miniplant : Rasa sedikit manis, gurih, dan } \\
\text { juicy/Miniplant : slightly sweet, tasteful, and } \\
\text { juicy taste }\end{array}$ & $\begin{array}{l}\text { Miniplant: rasa manis sedikit } \\
\text { berkurang, namun masih gurih dan } \\
\text { juicy/ Miniplant: slightly reduced } \\
\text { sweet taste, but still tasteful and juicy }\end{array}$ & $\begin{array}{l}\text { Miniplant: sedikit gurih, netral, tetapi } \\
\text { masih juicy/Miniplant: less tasteful, } \\
\text { tend to neutral, but still juicy }\end{array}$ \\
\hline $\begin{array}{l}\text { Pos : Rasa sedikit manis dan Juicy/Post: } \\
\text { slightly sweet and juicy taste }\end{array}$ & $\begin{array}{l}\text { Pos: rasa manis, gurih dan juicy } \\
\text { berkurang/Post: reduced sweet, } \\
\text { tasteful and juicy taste. }\end{array}$ & $\begin{array}{l}\text { Pos: rasa netral dan kurang juicy/Post: } \\
\text { neutral and less juicy taste. }\end{array}$ \\
\hline
\end{tabular}


tujuan dapat dilihat pada Tabel 2. Dari Tabel 2 terlihat ketika didaratkan panelis memberi nilai 9 dengan rasa sedikit manis, gurih dan juicy, baik tuna yang didarakan di miniplat maupun di pos pendaratan (Tabel 3). Rasa tuna loin mulai menurun nilainya ketika tuna loin dikemas, panelis memberikan nilai rasa yang lebih tinggi $(8,33)$ pada tuna loin yang didaratkan di miniplant dibandingkan dengan tuna loin yang didaratkan di pos pendaratan $(7,67)$. Pada saat dikemas tuna loin yang didaratkan di pos sudah kehilangan rasa manisnya (cenderung netral) dan kurang juicy. Hal ini disebabkan ikan tuna yang didaratkan di pos pendaratan sudah 2 hari dies sebelum dikemas sehingga menyebabkan aksi enzim endogen dalam jaringan ikan yang menghasilkan senyawa volatil yang menyebabkan terjadinya perubahan rasa. Panelis memberikan nilai rasa yang semakin menurun ketika tuna loin sampai ditempat pengiriman, dengan nilai 7,66 untuk ikan tuna yang didaratkan di miniplant dan 7,33 untuk tuna loin yang di daratkan di pos pendaratan. Menurunnya rasa disebabkan karena oksidasi asam lemak tak jenuh secara enzimatis dan non-enzimatis pada otot ikan yang menghasilkan senyawa karbonil, alkohol dan lain sebagainya sehingga menyebabkan perubahan pada rasa ikan (Tanako \& Osako, 2009).

\section{Evaluasi Sanitasi Sarana Prasarana Pengolahan yang digunakan}

Kondisi sanitasi tempat pengolahan merupakan salah satu faktor yang berpengaruh terhadap mutu loin yang dihasilkan. Hasil analisis bakteri $E$. coli dan Salmonella sp. yang digunakan sebagai indikator sanitasi dan higiene menunjukkan hasil yang negatif. Sedangkan angka lempeng total (ALT) dan koliform dapat dilihat pada Tabel 4. Bakteri koliform adalah bakteri intestinal yang hidup di saluran pencernaan manusia. Bakteri ini digunakan sebagai indikator adanya bakteri patogen pada air minum atau makanan. Sebelum melaut seharusnya kapal diinspeksi dengan memeriksa kebersihan kapal untuk menjamin tingkat sanitasi dan higiene kapal, sehingga tidak menjadi sumber kontaminasi.

Menurut Benjakul, Visessanguan, dan Tueksuban (2003) kandungan bakteri pada ikan dapat meningkat selama penanganan karena kontaminasi dari sarana parasana yang digunakan, yang pada dasarnya ketika ditangkap daging ikan kondisinya steril. Dalam penelitian ini semua sarana produksi yang digunakan mengandung jumlah bakteri yang cukup tinggi, $10^{5}$ $10^{6} \mathrm{koloni} / \mathrm{g}$ (Tabel 4) yang mencemari meja, palkah, stirofom, pisau dan timbangan yang digunakan. Akibat kondisi perahu dan sarana pengolahan yang tidak higienis tersebut dapat menyebabkan pengolahan loin yang dilakukan di atas perahu maupun di miniplant memiliki risiko terjadinya kontaminasi bakteri (patogen dan pembusuk) pada loin. Kondisi serupa juga dilaporkan oleh Jati et al. (2014) terhadap kondisi perahu yang digunakan oleh nelayan Asilulu yang kurang terjaga kebersihannya.

Kesadaran dan pengetahuan pekerja mengenai sanitasi akan sarana pengolahan yang digunakan menjadi kunci utama dalam menjaga kualitas produk yang dihasilkan. Demikian juga sarana produksi yang digunakan tidak boleh mencemari atau mengkontaminasi produk olahan yang dihasilkan. Analisis angka lempeng total (ALT) terhadap es yang digunakan menunjukkan jumlah bakteri yang cukup tinggi yaitu $1,47 \times 10^{6} \mathrm{koloni} / \mathrm{g}$ (Tabel 4), yang seharusnya angka ALT yang diijinkan adalah $10^{2}$ koloni/g. Es yang digunakan harus bersih dan saniter,

Tabel 4. Angka lempeng Total (ALT) dan Coliform pada sarana dan prasarana yang digunakan untuk pengolahan tuna loin

Table 4. Total Plate Count (TPC) and Coliform from the equipment used for tuna loin processing

\begin{tabular}{clcc}
\hline \multirow{2}{*}{ No } & \multicolumn{1}{c}{$\begin{array}{c}\text { Sarana dan Prasarana/ } \\
\text { Equipment }\end{array}$} & \multicolumn{2}{c}{ Parameter } \\
\cline { 3 - 4 } & & & ALT (Coloni/g) \\
\hline Kapal/Boat & $4.7 \times 10^{6}$ & 235 \\
\hline 1 & Meja pengolahan/Processing table & $1.9 \times 10^{6}$ & 185 \\
2 & Palka/fishing vessel & $8.7 \times 10^{5}$ & 160 \\
3 & Stirofom/Styrofoam & & 90 \\
\hline Miniplan/Miniplant & $1.3 \times 10^{6}$ & 160 \\
\hline 1 & Meja pengolahan/Processing table & $6.3 \times 10^{5}$ & 44 \\
2 & Pisau/Knife & $1.4 \times 10^{6}$ & 124 \\
3 & Timbangan/Balance & $1.1 \times 10^{6}$ & 19 \\
4 & Es/lce & $1.7 \times 10^{6}$ & 180 \\
5 & Pekerja/Workers & $1.7 \times 10^{6}$ & \\
6 & Stirofom/Styrofoam & &
\end{tabular}


dibuat dari air yang memenuhi persyaratan sesuai dengan SNI 014872.12006 (BSN $\left.{ }^{3}, 2006\right)$. Dalam penggunaannya es harus ditangani dan disimpan di tempat yang bersih dan terhindar dari kontaminasi. Tingginya angka ALT pada es yang digunakan di beberapa miniplant yang diambil sampelnya kemungkinan karena adanya kontaminasi dari es yang sudah digunakan untuk pengesan sebelumnya. Sedangkan swabyang dilakukan pada tangan pekerja menunjukkan bahwa rata-rata jumlah bakteri sebesar $1,7 \times 10^{6} \mathrm{koloni} / \mathrm{g}$ (Tabel 4). Tingginya jumlah bakteri pada tangan pekerja dapat mencemari tuna loin yang dihasilkan.

\section{Evaluasi Implentasi GMP di miniplant tuna loin}

Evaluasi terhadap implementasi GMP di miniplant tuna loin di Ambon berdasarkan kriteria persyaratan teknis Kep Men No. 52A/KEPMEN/2013 menunjukkan bahwa miniplant yang dievaluasi hanya 59\% dari kriteria yang memenuhi persyaratan teknis. Kriteria yang tidak memenuhi persyaratan antara lain fasilitas karyawan, tempat penyimpanan bahan kimia, bahan kimia dan bahan berbahaya, kebersihan dan kesehatan karyawan, sanitasi dan pelatihan karyawan (Tabel 5). Demikian juga fasilitas karyawan untuk tempat cuci tangan yang dilengkapi dengan sabun

Tabel 5. Evaluasi implementasi GMP di miniplant berdasarkan persyaratan teknis Kepmen No 52A/KEPMEN/ 2013

Table 5. Evaluation on the GMP implementation in miniplant in conformity with the Minister of Marine Affairs and Fisheries regulation No 52A /KEPMEN/2013

\begin{tabular}{|c|c|c|c|c|c|}
\hline \multirow{2}{*}{$\begin{array}{l}\text { Evaluasi parameter/ } \\
\text { Evaluation parameter }\end{array}$} & \multirow{2}{*}{$\begin{array}{c}\text { Jumlah } \\
\text { atribut yang } \\
\text { dievaluasi/ } \\
\text { Number of } \\
\text { atribute } \\
\text { evaluated }\end{array}$} & \multicolumn{2}{|c|}{$\begin{array}{l}\text { Sesuai Standar/ } \\
\text { In conformity with } \\
\text { standard }\end{array}$} & \multicolumn{2}{|c|}{$\begin{array}{c}\text { Tidak Sesuai } \\
\text { Standar/ } \\
\text { Not conformity with } \\
\text { standard } \\
\end{array}$} \\
\hline & & $\begin{array}{l}\text { Jumlah/ } \\
\text { Amount }\end{array}$ & $\%$ & $\begin{array}{l}\text { Jumlah/ } \\
\text { Amount }\end{array}$ & $\%$ \\
\hline Lokasi/Location & 9 & 3 & 33 & 6 & 67 \\
\hline Ventilasi/Ventilation & 2 & 1 & 50 & 0 & 50 \\
\hline Fasilitas karyawan/Employee facility & 11 & 2 & 18 & 9 & 82 \\
\hline Penerangan/Lighting & 1 & 1 & 100 & 0 & 0 \\
\hline Saluran air pembuangan/Waste water tunnel & 2 & 2 & 100 & 0 & 0 \\
\hline Tempat penyimpanan bahan kimia/Chemical storage & 2 & 0 & 0 & 2 & 100 \\
\hline $\begin{array}{l}\text { Persyaratan kontruksi ruang penanganan dan } \\
\text { pengolahan/Construction Requirements on handling and } \\
\text { processing room }\end{array}$ & 25 & 17 & 68 & 8 & 32 \\
\hline Penerimaan bahan/Acceptance materials & 2 & 2 & 100 & 0 & 0 \\
\hline $\begin{array}{l}\text { Bahan pembungkus dan pengemas/Wrapping and } \\
\text { packaging materials }\end{array}$ & 5 & 4 & 80 & 1 & 20 \\
\hline Air / Water & 4 & 3 & 75 & 1 & 25 \\
\hline Es/lce & 3 & 2 & 67 & 1 & 33 \\
\hline Penanganan limbah/Waste treatment & 4 & 3 & 75 & 1 & 25 \\
\hline $\begin{array}{l}\text { Bahan kimia dan bahan berbahaya/ Chemicals and } \\
\text { hazardous substances }\end{array}$ & 4 & 0 & 0 & 4 & 100 \\
\hline $\begin{array}{l}\text { Kebersihan dan kesehatan karyawan/Hygiene and health } \\
\text { of employees }\end{array}$ & 2 & 0 & 0 & 2 & 100 \\
\hline Sanitasi/Sanitation & 2 & 0 & 0 & 2 & 100 \\
\hline $\begin{array}{l}\text { Prosedur untuk melindungi produk pada setip tahapan } \\
\text { produksi/Procedures to protect the product at each stage } \\
\text { of the production }\end{array}$ & 1 & 1 & 100 & 0 & 0 \\
\hline Penanganan bahan baku/Handling of raw material & 9 & 7 & 78 & 2 & 21 \\
\hline Pengendalian proses/Proccess control & 8 & 8 & 100 & 0 & 0 \\
\hline $\begin{array}{l}\text { Pelatihan karyawan dan penanggung jawab/Training of } \\
\text { employee and person in charge }\end{array}$ & 2 & 0 & 0 & 2 & 100 \\
\hline $\begin{array}{l}\text { Pencatatan dan dokumentasi/Recording and } \\
\text { documentation }\end{array}$ & 2 & 2 & 100 & 0 & 0 \\
\hline Proses pengolahan tuna loin/Processing of tuna loin & 100 & 59 & 68 & 41 & 42 \\
\hline
\end{tabular}


pembersih, untuk mengurangi kemungkinan penyebaran bakteri oleh pekerja juga tidak ada. Sedangkan bak cuci kaki sebetulnya tersedia, tetapi tidak difungsikan sebagaimana mestinya. Hal ini disebabkan fasilitas tersebut belum dipahami betul oleh pemilik miniplant mengenai fungsi dan pengaruhnya terhadap produk hasil perikanan yang diolahnya. Kriteria lain yang tidak memenuhi persyaratan dalam standar GMP adalah suhu ruang proses dan kontruksi ruang penanganan dan pengolahan tidak memenuhi persyaratan untuk pengolahan tuna loin. Ruang proses tidak tertutup dengan baik dengan suhu ruang proses masih tinggi $\left(28^{\circ} \mathrm{C}\right)$. Lingkungan tempat pengolahan merupakan faktor yang berpengaruh terhadap mutu fillet yang dihasilkan. Jika mengacu pada regulasi di Islandia, menurut the Administration of Occupational Safety and Health (AOSH), suhu tempat pengolahan dipersyaratkan mendekati $16{ }^{\circ} \mathrm{C}$, tetapi tidak boleh lebih rendah dari $10^{\circ} \mathrm{C}$ (Valtýsdóttir, Margeirsson, Arason, Lauzon, \& Martinsdóttir, 2010). Hal ini disebabkan bahwa kenaikan suhu tuna loin tergantung dari suhu ruang pada ruang proses, suhu tuna loin dapat bertambah 6-7 ${ }^{\circ} \mathrm{C} / \mathrm{jam}$ jika ruang proses suhunya lebih dari $20^{\circ} \mathrm{C}$ (Gang, 2013). Peningkatan suhu selama proses dapat berpengaruh terhadap menurunnya daya simpan serta mutu tuna loin yang dihasilkan. Pasokan air bersih di tempat miniplant hanya mengandalkan sumur air dangkal, yang rentan terhadap intrusi pergerakan air sekitarnya sehingga kualitas air sewaktu waktu bisa berubah. Hal lain adalah minimnya pelatihan yang diadakan oleh Dinas terkait setempat, baik mengenai sanitasi maupun penanganganan tuna segar.

\section{KESIMPULAN}

Dari hasil penelitian ini dapat diperoleh informasi bahwa tuna loin yang didaratkan mempunyai rata rata suhu pusat dengan kisaran $10,56-16,53^{\circ} \mathrm{C}$ jauh di atas suhu $4,4^{\circ} \mathrm{C}$ untuk tuna sashimi. Berdasarkan kandungan TVBnya ikan tuna yang didaratkan sudah tidak tergolong dalam mutu prima, tetapi tergolong dalam mutu segar dengan kandungan TVB yang berkisar 13,6 -14,04 mgN\%. Secara sensori (kenampakan) terlihat adanya lapisan pelangi tipis pada permukaan tuna loin yang mengindikasikan ikan tuna mengalami stres sebelum dimatikan.

Pengiriman tuna segar ke luar Kota Ambon berpengaruh terhadap menurunnya sifat sensori serta meningkatnya angka lempeng total bakteri yang diamati. Ikan tuna yang didaratkan di pos pendaratan dan kemudian baru dikirim 2 hari kemudian, menyebabkan terjadinya penurunan nilai sensori dan meningkatkan jumlah angka lempeng total bakteri yang lebih cepat, namun tuna loin masih tergolong tuna loin segar untuk sashimi. Hasil swab pada kapal dan miniplant tuna loin yang dilakukan menunjukkan bahwa sarana prasarana yang digunakan kurang terjaga kondisi sanitasinya dengan jumlah bakteri berkisar antara $10^{5}-10^{6} \mathrm{koloni} / \mathrm{g}$ yang dapat mengkontaminasi produk tuna loin yang dihasilkan. Es yang digunakan mengandung jumlah bakteri yang cukup tinggi yaitu $10^{6} \mathrm{koloni} / \mathrm{g}$, jauh dari persyaratan jumlah bakteri untuk es balok untuk penanganan ikan yaitu $10^{2} \mathrm{koloni} / \mathrm{g}$.

Implementasi GMP berdasarkan kriteria teknis menurut KepMenKP Nomor: KEP52A/KEPMEN/2013 mengenai Persyaratan Jaminan Mutu dan Keamanan Hasil Perikanan pada Proses Produksi, Pengolahan, dan Distribusi, terhadap miniplant hanya 59\% kriteria yang memenuhi persyaratan.

\section{DAFTAR PUSTAKA}

Amegovu, A. K., Serunjogi, M. L., Ogwok, P., \& Makokha, V.(2012). Nucleotited degradation products, total volatile basic nitrogen, sensory and micribiological quality of nila pearch (Lates niloticus) fillets under chilled storage. J. of Microbiology, Biotechnology and Food Sciences, 2, 653-666.

Anonim. (2015). Buku Laporan Tahunan Propinsi Maluku. Kanwil Tingkat I Maluku.

Anonim. (1995). Recommendation for on Board Handling of Pursein Caught Tuna. Fisheries Research. San Diego, 4.

Anonim. (2010). Instruction Manual of Sanitakun. http:// www.jnc-corpco.Jp/Sanita/sanita-kun@jnc.corp.co.jp. Diakses tanggal 12 Mei 2016.

Badan Standarisasi Nasional (BSN) ${ }^{\mathrm{A}}$.(2006).SNI 01 2693.2-2006. Tuna segar untuk sashimi Bag 2: persyaratan bahan baku.

Badan Standarisasi Nasional (BSN) ${ }^{\text {B }}$. (2006). SNI 01.4872.1- 2006 Es balok untuk penanganan ikan

Badan Standardisasi Nasional (BSN) ${ }^{\mathrm{C}}$. (2006). SNI 01.2354 - 2006 Standar Nasional Indonesia. Cara uji kimia pada produk Perikanan

Badan Standarisari Nasional (BSN) ${ }^{\mathrm{D}}$. (2006).SNI 01.2346 Petunjuk pengujian organoleptik dan atau sensori.

Badan Standarisasi Nasional (BSN). (2009). SNI 7530.1.2009. Tuna loin segar bagian 1 : spesifikasi

Bao, H. N. D., Arason, S., \& lorarinsdottir, K. A. (2007). Effects of dry ice and superchilling on quality and shelf life of artic charr (Salvellinus alpinus). International Journal of Food Enginering, 3(3), 1-27.

Bartram, P., Garrod, P., \& Kaneko, J. (1996). Quality and Product Differentiation as Price Deteminations in the marketing of fresh pacific tuna and marlin. Pelagis Fisheries Research Program. University of Hawaii. 50.

Benjakul, S., Visessanguan, W., \& Tueksuban, J. (2003). Changes in physico-chemical properties and gelforming ability of lizardfish (Saurida tumbil) during post-mortem storage in ice. Food Chemistry 80 535544. 
Evaluasi mutu tuna loin segar untuk sashimi yang diolah di atas perahu..........(Theresia Dwi Suryaningrum et al.)

Blanc, M., Desurmont, A., \& Beverly, S. (2005). Onboard handling of sashimi-grade tuna: a practical guide for crew members. Sec retariate of the Pacific Community. Noumea. $24 \mathrm{pp}$.

Boue, F. B. (2015). What's the temperature in airliner's cargo hold? http//www.quora.com. Whats-thetemperature-in-an-airliners-cargo-hold. Diakses tanggal 3 April 2016.

Chong, Y. T. (2012). Risk management of emerging foodborne diseases. Singapore Management Journal, 1(2), 34-52.

Cramer, J. L., Nakamura, R. M., Dizon, A. E., \& Ikehara, W. N. (1981). Burn tuna. Conditions leading to rapid deterioration in the quality of raw tuna. Marine Fisheries Rewiew, 43(6), 12-16.

Fardiaz, S., \& Jenie B. S. L. (1989). Uji sanitasi dalam industri pangan. PAU Pangan dan Gizi IPB. Bogor

Fukusima, H., Maeda, T., \& Fukuda, Y. (2012). Biochemical changes of fish during catch and subsequent short-term rearing in fukuda Y.W (ed) Quality Improvement of coastal Fish and Marine Invertebrates. Kouseisha-Kouseikaku. Tokyo. 3545.

Gang, M. (2013). Changes in the quality and yield of fish fillets due to temperature fluctuation during processing. United Nations University Final Project. Fisheries Training Programme. Icelanf (Final project).

Ganis, L. R. (2013). Menghitung kebutuhan es dalam pengawetan ikan. Media Penyuluh Perikanan On line.2.

Goodrick, G. B., Thomas, P. T., Paterson, B. D., \& Smart, A. (2002). Effect of husbandry and handling techniques on the post harvest quality of farmed souther bleufin tuna. Tuna SBT Aquaculture Program

Huss, H. H. 1988. Fresh fish- quality and quality changes. Training Manual Rome: United Nations. Food and Agriculture Organization and Denish International Development Agency: FAO/DANIDA.

Hardiana, P. K. (2009). Evaluasi resiko semi quantitative kadar histamin ikan tuna pada proses pembongkaran di transit dan pengolahan produk tuna loin beku, Skripsi, Fak Perikanan. Institut Pertanian Bogor. 168.

Irianto., H. E. (2008). Teknologi penanganan dan penyimpanan ikan tuna segar di atas kapal. Squalen, 3(2), 41-50.

James, S. J., James, C., \& Evans, J. A. (2006). Modelling of food transportation system. a review. International Journal of Refrigeration, 29 (9), 947-957.

Jati, A. K., Nurani, T. W., \& Iskandar. (2014). Sistem rantai pasok tuna loin di perairan Maluku. Marine Fishries, 5(2), 171-180

Jinadasa, B. K. K. K., Galhena, C. K., \& Liyanage, N. P. P. (2015). Histamine formation and the freshness of yellowfin tuna (Thunnus albacores) stored at different temperature. Cogent Food \& Agriculture,1,1-10.

Jinadasa, B. K. K. K. (2014). Determination of quality of marine fishes based on total volatile base nitrogen test (TVB-N). Nature and Science, 12 (5),106 -111.

Kalantari, H., Behfar, A., Nazari, Z., Kalatari, M., \& Hosseini, H., (2015). Occurrence of histamine in canned tuna fish produced of two major manufactories in khuzestan province By HPLCHplc Method. Int.J.Curr.Res.Chem.Pharma.Sci., 2(10), 9-15.

Kementrian Kelautan dan Perikanan RI. (2013). Keputusan Menteri Kelautan dan Perikanan Republik Indonesia Nomor Kep 52A/KEPMEN/2013 Tentang Persyaratan Jaminan Mutu dan Keamanan Panagan Hasil Perikanan pada Proses Produksi, Pengolahan dan DIstribusi. 30.

Maeda, T., Yaguchi, S., Fukushima, H., Harada, K., \& Fukuda, Y. (2014). Post catch fish handling for high quality fish products. Jurnal of National Fisheries University, 62(4),55-158.

Mai, N. T., Margeirsson, B., Margeirsson, S., Bogason, S. G., Sigurgisladottir, S., \& Arason, S. (2012). Temperature mapping of fresh fish supply chainsair and sea transport. Journal of Food Process Engineering, 35(4), 622-656.

Martinsdottir, E., Lauzon. H. L., Margeirsson, B., Sveinsdottir, K., Povaldsson. L., Magnuson, H., \& Eden, M. (2010). The effect of colling methods at processing and used of gels pack on storage life of cod (gadus morhua) loin: Matis Report 10-18 Rekyavik Ireland .

Masniyom. P. (2008). Deterioration and self life extension of fish and fishery products by modified atmosphere packaging. Songklanakarin J. Sci, Technol., 33 (2) 181-192.

Mc Lauchin, J., Little, C. L., Grant, K. A., \& Mithan, V. 2005. Scrombrotoxic fish poisoning. J. of Public Health, 28 (1), 61-62.

Murtini, J. T., Riyanto, R., Priyanto, N., \& Hermana, I., (2014). Pembentukan Formaldehyde alami pada beberapa jenis ikan laut selama penyimpanan dalam es curia. Jurnal Pascapanen dan Bioteknologi Perikanan, 9(2),143-157.

Muscolino, D., Giarratana, F., Beninati, C., Tornambene, A., Paneblanco, A., \& Zlino, G. (2014). Hygienic, sanitary evaluation of sushi and sashimi sold in Messina \& Catenia Italy. Italian Journal Food Safety, 3(1701), 134-136.

Nurbrega, C. C., Mendes, P. P., \& Mendes, E. S. (2014). Factors that determinethe quality of big eye tuna cought in the western tropical Atlantic Ocean. Arq. Bras, Med, Vet. Zootec.,66(3),7.

Ozogul, Y. (2010). Methods for freshness quality and deterioration In: Handbook of Seafood and Seafood Product analysis. Edited by: Leo M.L. Nollet and Fidel Todrá. CRC Press. Taylor and Francis Group. Boca Rato. USA. 189 - 214

Özyurt, G., E., Kuley, S., Özkütük, \& Özogul, F. (2009). Sensory, microbiological and chemical assessment of the freshness of red mullet (Mullus barbatus) and goldband goatfish (Upeneus moluccensis) during storage in ice. Food Chem., 114, 505-510.

Quang , N. H. (2005). Guidelines For Handling and Preservation of Fresh Fish for Futher Processing in Vietnam. The United Nations University. Fisheries Training Programme. Reykjavik Iceland. 38.

Sangaji, S., Mustarudin, \& Wisudo, S. H., (2013). Pengaruh Faktor Produksi terhadap Pengembangan Perikanan 
Tuna di Kota Ambon. Jurnal Teknologi Perikanan dan Kelautan, 4(1), 1-8.

Siregar, R. R., Siregar, A. P., \& Zahro, S. (2014). Penanganan dan pengolahan ikan tuna (Thunnus $S p)$ loin segar di atas kapal hingga pada tingkat suplier di Desa Asilulu, Ambon-Maluku. Jurnal-STP, 21,1-8.

Supriyanto, K. H. (2011). Analisis teknis dan ekonomis perencanaan sistem pendingin ruang palkah ikan dengan sistem kompresi uap menggunakan refrigeran R 22 (Monochloro Difloro Metana). Kapal. 8(1), 6-15.

Suryaningrum, T. D., Purnomo, A. H., Ikasari, D., \& Octavini, H. (2016). Teknologi proses dan standar pengolahan tuna loin. Laporan Teknis. Pusat Penelitian dan Pengembangan Daya Saing Produk dan Bioteknologi kelautan dan Perikanan. 126.

Susanto, E., Agustini, T. W., Ritanto, E. P., Dewi, E. N., \& Sastawati. F. (2011). Changes in oxidation and reduction potensial (Eh) and $\mathrm{pH}$ of Tropical Fish during storage. Jurnal of Coastal Development, 14(3), 223-234.

Syarif, B., Suwardiyono, \& Gautama, (2012). Penangkapan dan Penanganan Ikan Tuna Segar di Kapal Rawai Tuna. Balai Besar Pengembangan dan Penangkapan Ikan. Semarang. 79.

Tanako, M. \& Osako, K. (2009). Bantuan teknis untuk industri ikan dan udang skala kecil dan menengah di Indonesia. Kerjasama Dept Kelautan dan Perikanan dan JICA. Jica Project. University. Montral Quebec Canada.79.

Ushiyama, M. \& Iwasaki, M. (2010). Evaluation of sanitakun E. coli \& coliform sheet medium for the enumeration of total coliforms and E. coli. Journal AOAC Intl., 93(1), 163-83.

Valtýsdóttir, K. L., Margeirsson, B., Arason, S., Lauzon, H. L., \& Martinsdóttir. E. (2010). Guidelines for precooling of fresh fish during processing and choice of packaging with respect to temperature control in cold chains. Reykjavik Matis.

Watson, C., Bourke, R. E., \& Brill, R. W. (1988). A comprehensive theory on the etiology of brun tuna. Fishery Bulletin, 86(2), 367- 371.

Wibowo, S., Utomo B. S. B., Suherman, M., \& Putro, S. (2007). Penanganan Ikan Tuna Segar untuk Ekspor ke Uni Eropa. Buku Panduan. Balai Besar Riset Pengolahan Produk dan Bioteknologi Kelautan dan Perikanan. Badan Riset Kelautan dan Perikanan. DKP Jakarta 2007.

Widiastuti, I, \& Putro, S, (2010). Analisis Mutu Ikan Tuna selama lepas Tangkap. Maspari Jurnal, 01, 22-29.

Widiastuti, I., Putro, S., Fardiaz, D., Trilaksani, W., \& Inaoko, T. (2012). Changes in freshness of steak and loin tuna (Thunnus albacores) during 15 days Chilled stored. $J$ of Fisheries and aquatic Science.1-11.

Wu, T. H. \& Bechiel, P. J. (2008). Ammonia dimethylamine, trimethylamine, and trimethylamine oxide from raw and processed fish by-products. Journal of Aquatic Food Product Technology, 17, 27 38.

Yunizal, Murtini, J. T., Dolaria, N., Purdiwoto. B., Abulrochim, \& Charkipan. (1998). Prosedure Analisa Kimiawi Ikan dan Produk Olahan Hasil Hasil Perikanan. Instalasi Penel Perikanan Laut Slipi. Balai Penelitian Perikanan Laut. Pusat Penelitian dan Pengembangan Perikanan. Jakarta.100. 